\title{
Use of New BTH Derivative as Supplement or Substitute of Standard Fungicidal Program in Strawberry Cultivation
}

\author{
Maciej Spychalski ${ }^{1}{ }^{(D}$, Rafal Kukawka ${ }^{1,2}{ }^{D}$, Włodzimierz Krzesiński ${ }^{3}{ }^{D}$, Tomasz Spiżewski ${ }^{3}$, \\ Monika Michalecka ${ }^{4}$, Anna Poniatowska ${ }^{4}\left(\mathbb{D}\right.$, Joanna Puławska ${ }^{4} \mathbb{D}$, Monika Mieszczakowska-Frąc ${ }^{4}(\mathbb{D}$, \\ Katarzyna Panasiewicz ${ }^{5}$, Anna Kocira ${ }^{6}$ (D) and Marcin Smiglak ${ }^{1,2, *(D)}$
}

1 Poznan Science and Technology Park, Adam Mickiewicz University Foundation, ul. Rubież 46, 61-612 Poznań, Poland; m.spychalski00@gmail.com (M.S.); kukawka.rafal@gmail.com (R.K.)

2 Innosil Sp. z o.o., ul. Rubież 46, 61-612 Poznań, Poland

3 Department of Vegetable Crops, Faculty of Agronomy, Horticulture and Bioengineering, Poznań University of Life Sciences, ul. Dabrowskiego 159, 60-594 Poznań, Poland; wlodzimierz.krzesinski@up.poznan.pl (W.K.); tomasz.spizewski@up.poznan.pl (T.S.)

4 The National Institute of Horticultural Research, ul. Konstytucji 3 Maja 1/3, 96-100 Skierniewice, Poland; monika.michalecka@inhort.pl (M.M.); anna.poniatowska@inhort.pl (A.P.); joanna.pulawska@inhort.pl (J.P.); monika.mieszczakowska@inhort.pl (M.M.-F.)

5 Department of Agronomy, Faculty of Agronomy, Horticulture and Bioengineering, Poznan University of Life Sciences, ul. Wojska Polskiego 28, 60-637 Poznań, Poland; katarzyna.panasiewicz@up.poznan.pl

check for updates

Citation: Spychalski, M.; Kukawka,

R.; Krzesiński, W.; Spiżewski, T.; Michalecka, M.; Poniatowska, A.; Puławska, J.; Mieszczakowska-Frac, M.; Panasiewicz, K.; Kocira, A.; et al. Use of New BTH Derivative as Supplement or Substitute of Standard Fungicidal Program in Strawberry Cultivation. Agronomy 2021, 11, 1031. https://doi.org/10.3390/ agronomy11061031

Academic Editor: Carlos García Delgado

Received: 31 March 2021

Accepted: 17 May 2021

Published: 21 May 2021

Publisher's Note: MDPI stays neutral with regard to jurisdictional claims in published maps and institutional affiliations.

Copyright: (c) 2021 by the authors. Licensee MDPI, Basel, Switzerland. This article is an open access article distributed under the terms and conditions of the Creative Commons Attribution (CC BY) license (https:// creativecommons.org/licenses/by/ $4.0 /)$.
6 Institute of Agricultural Sciences, State School of Higher Education in Chełm, Pocztowa 54, 22-100 Chełm, Poland; akocira@pwsz.chelm.pl

* Correspondence: marcin.smiglak@ppnt.poznan.pl; Tel.: +48-782-707-596

Abstract: Triggering the plant resistance induction phenomenon by chemical compounds, for example acibenzolar-S-methyl ester, has been known and described in scientific literature. Other benzothadiazole derivatives have been also described; however, their properties have not been sufficiently studied. The tested substance, $N$-methyl- $N$-methoxyamide-7-carboxybenzo(1.2.3)thiadiazole (BTHWA), is an amide derivative of benzothiadiazole, showing a stimulating effect on plant growth, apart from its plant resistance inducing activity. This article presents the impact of BTHWA, used solo and in the program with fungicides, on the strawberry plants development, fruits health, yield, and quality parameters of the crop. The results show that the combined use of BTHWA and fungicides had a positive impact on the plants health and fruit health and nutraceutical and nutritional composition of compounds when compared to the results obtained when strawberries were treated only with the BTHWA or the fungicide. As a result of BTHWA use, the partitioning of assimilates has changed, which directly translated into the results of the conducted experiments. A reduction in the respiration of the fruit during storage was also observed, possibly due to a reduced disease infestation and a lower dry matter content in the fruit. A correlation between the parameters determined during the experiment was found. The BTHWA mode of action was evidenced to be beneficial to strawberry plants and fruit.

Keywords: strawberry cultivation; benzothiadiazole; plant stimulant; plant resistance inducer

\section{Introduction}

The European Union Biodiversity Strategy for 2030 has been adopted as a long-term plan for protection of the nature and reversal of ecosystems degradation [1]. Among key actions to be taken are revision of the sustainable use of pesticides pointing to the importance of Integrated Pest Management provisions. The activities mentioned are intended at achieving the reduced use, risk, and dependence on pesticides extensively used in agriculture. Concurrently, increasing consumer awareness forces legislators to withdraw from the market the most toxic pesticides and reduce the number of treatments with pesticides, which opens an urgent need to find new methods for crop protection. 
As plants are unable to escape from stressful conditions, they evolved diverse mechanisms allowing them to respond to different types of stress including infectious agents. In case of contact with pathogen, plants activate various defense mechanisms including the systemic acquired resistance (SAR) characterized by the increased expression of pathogenicrelated genes (PR genes) in the plant's tissues [2]. However, SAR can be activated using substances that mimic plant-pathogen interaction [3].

Currently, one of the most studied inducers of plant resistance is benzo(1.2.3)thiadiazole7-carboxylic acid, S-methyl ester, an active substance of commercially available Syngenta product Bion 50 WG and Actigard 50 WG. Meller-Harel et al. and Gutierrez et al. have shown that induction of strawberries resistance by application of Trichoderma harzianum, acibenzolar-S-methyl (BION), SCNB2 inductor or isolates of bacteria or yeast, can effectively restrict powdery mildew (Podosphaera aphanis) on the strawberry leaves [4,5].

The advantages following from the employment of SAR phenomena, including the facts that: (i) plant resistance inducers are safe to the environment and used in extremely low dosages [6]; (ii) pathogens cannot develop immunity against SAR inducers in contrary to the resistance developed toward plant protection agents and the resistance effect is durable [7]; (iii) they activate resistance against a broad spectrum of pathogens at the same time [8], imply that improvement of plant resistance to a broad spectrum of pathogens in field conditions seem highly attractive. However, in most plants, the activation of defense systems results in the partial suspension of growth $[9,10]$. This phenomenon is commonly known as the growth-defense trade-off. When the plant shifts its metabolism to activate defense systems, plant growth and development can be partially disturbed. The reverse mechanism is observed when the intense growth and developmental processes suppress immune responses, related to for example salicylic acid production [11].

Treatment of plants with salicylic acid or salicylic acid functional-analog, e.g., benzothiadiazole (BTH) leads to plant growth reduction [9,12]. It has been shown that treatment with BTH increased the disease resistance when Arabidopsis plants were pretreated either with mock or benzothiadiazole (BTH) $73.6 \mathrm{mg} / \mathrm{L}$ and then inoculated with Pseudomonas syringae pv tomato 1 day later. Three days later, the bacteria (measured as the logarithm of colony forming units per plant) was around $5.5 \mathrm{Log}(\mathrm{cfu}) / \mathrm{plant}$ and 2.6 Log(cfu)/plant, respectively. The plant average fresh weight before bacterial extraction was around $8.1 \mathrm{mg}$ for mock inoculated plants and around $7 \mathrm{mg}$ for BTH-treated plants, respectively [13]. Many studies have shown a relationship between salicylic acid use and the growth and development of plants. However, in another study, when Rosmarinus officinalis L. was sprayed with various concentrations of salicylic acid (450, 300, and $150 \mathrm{mg} / \mathrm{L}$ ), a significant increase in growth rates and photosynthesis levels compared to untreated plants was reported. The increase was more pronounced when spraying plants with a concentration of $300 \mathrm{mg} / \mathrm{L}$ [14].

Our hitherto study has been focused on the synthesis of ionic derivatives of benzo(1.2.3)thiadiazole-7-carboxylic acid and isonicotinic acid acting as dual functional salts [15-19]. The dual functionality of the synthesized salts, known as the ionic liquids, was preserved by maintaining resistance inducing properties with additional direct antibacterial function $[15,17,18]$. The most effective salts, which were functional analogues of salicylic acid and BTH derivatives, allowed $100 \%$ induction in tobacco in the tobacco mosaic virus (TMV) model, at the same time demonstrating high antibacterial activity towards plant pathogens [16]. Another study, using the most effective plant resistance inducer discovered by us, N-methoxy-N-methylbenzo(1.2.3)thiadiazole-7-carboxamide (BTHWA), exhibited high inducing efficacy confirmed by molecular studies [20]. The plants treated with BTHWA solution have shown a higher level of SAR marker genes $P A L$, $N P R 1$, and $P R-1 b$ at $4 \mathrm{~h}$ after the treatment in comparison to the untreated control. These marker genes are associated with different signaling pathways (salicylic acid, jasmonate, and ethylene pathway) and in general with a pathogen defense response. Moreover, plants treated with BTHWA solution and after 7 days infected with the TMV virus exhibited a lower level of viral RNA accumulation then the control, thus the viral replication was 
less efficient. The experiments carried out on tobacco infected by the virus prior to the treatment with BTHWA showed similar results-viral replication was lowered, thus the BTHWA had a positive effect on the plant host.

Strawberry (Fragaria $\times$ ananassa Duch.) is a popular species of berry plants, cultivated all over the world. The fruits of this species are highly appreciated as a source of macro- and microelements, vitamins, and prohealth antioxidants [21-23]. The annual production in recent years has reached $9.2 \mathrm{Mt}$ [24]. Poland is the second largest producer of strawberries in Europe, with a production of over 176 thousand tons of strawberries from the area of 49,700 ha [25]. Growing competition along with growing expectations as to the quality and durability of the fruit, stimulate the efforts to increase the productivity of commercial plantations through introduction of new more efficient variations or more advanced technologies [26]. At the present stage of knowledge, it is obvious that new technologies must be environmentally friendly or at least neutral and improve the quality of the product. According to Fagherazzi et al., as far as production of strawberries is concerned, achievement of high yields and desired physicochemical properties of the fruit needs the use of plants of high quality and high initial vigor [27]. As follows from the hitherto research, the employment of resistance inducers may be an interesting and promising alternative for improvement of the fruit quality, including disease control in the post-harvest period. The importance of strawberries in the human diet is well-known due to its anticancerogenic, anti-inflammatory, and antineurodegenerative properties. Such properties are a result of a composition of bioactive compounds, including polyphenols, which are characterized by a strong antioxidant and antiproliferative activity $[28,29]$. The presence of these components determines the quality, nutritional value, and sensorial properties of strawberries [30]. Unfortunately, an important problem in strawberry production and storage are the fungal pathogens [31-33]. According to Parker, strawberries are considered to have the highest levels of pesticide residues of any fruit or vegetable available for retail sale [34]. The necessity of extensive usage of pesticides is questioned since the awareness of consumers and alternative producers regarding possible impact of extensive use of pesticides in fruit cultivation is growing. On the contrary, it is argued that by the responsible use of pesticides the residues level may be controlled and monitored to assure their safety. It is also indicated that there are no alternatives to large scale farming with the assistance of various chemicals to meet the world's food demand [35,36].

The general aim of the study undertaken was to check the effect of using a new active substance representing benzothiadiazoles, a BTH derivative, namely $\mathrm{N}$-methyl$\mathrm{N}$-methoxyamide-7-carboxybenzo(1.2.3)thiadiazole (BTHWA), on the field cultivation of strawberries. The experimental variants of treatment were intended to demonstrate the possibility of reducing the number of fungicide treatments in strawberry cultivation by supplementing them with the new plant resistance inducer or even completely replacing the use of fungicides with the new substance. Demonstration of such a possibility assumed not only the assessment of SAR inducing effect of the new active substance (used solo or in combination with one fungicide treatment) in comparison with protection provided by standard fungicide program, but also checking whether the growth-immunity tradeoff phenomenon occurs, and if so, to what extent. For this purpose, typical parameters assessed in the field experiment such as: marketable, non-marketable, and total yield; mean weight of marketable fruit; diseases development of fruit in the field and during storage; physicochemical parameters of fruit including content of anthocyans, polyphenols, ascorbic acid, firmness, color, dry weight, Brix, and respiration rate; the plant size were analyzed.

This report presents results concerning the unravelling of the mechanisms of activity of the new substance proposed (BTHWA) and for the first time tested in the field. The results presented so far have been obtained in the model experiments and aimed at determination of the molecular mechanisms of BTHWA activity. The lack of observations and measurements performed in greenhouse or field cultivation prevented a comprehensive analysis of the effect of BTHWA effect on the plants. The objective of the study was to evaluate the effect of BTHWA on the basis of measurements and calculations of a number 
of parameters describing the plants growth, their fruit bearing and effects of storage of the fruit in a refrigerator. The results were subjected to statistical analysis to find possible correlations between them, which would help deeper analysis of the BTHWA impact.

\section{Materials and Methods}

\subsection{Tested Substance}

The substance studied was $N$-methoxy- $N$-methylbenzo(1.2.3)thiadiazole-7-carboxamide (BTHWA) (Figure 1) obtained in our group [37], which is a derivative of benzothiadiazole whose resistance inducing effect on plants has been described in the literature [3]. The best known benzothiadiazole derivatives used for inducing plant resistance are the first commercially available "plant activator" benzo(1.2.3)thiadiazole-7-carbothioic acid, S-methyl ester (acibenzolar-S-methyl ester, ASM, BTH, CGA245704) and benzo(1.2.3)thiadiazole7-carboxylic acid, which were used as a platform for designing the new compound in which the active ingredient has been transformed from an acid to amide ( $N$ - methoxy- $N$ methylamide). The use of the proposed substance with this modification has brought about changes in the key physicochemical properties (Table 1), most importantly it improved water solubility of the substance from 7 to $20 \mathrm{mg} / \mathrm{L}$. The proposed substance, denoted as BTHWA, obtained with $99.9 \%$ purity, was used for preparation of a SC type formulation (concentrated liquid suspension). In this formulation BTHWA in the form of solid particles is dispersed in the liquid containing polymeric dispersant and thickening agent in the form of a polysaccharide ensuring homogeneous dispersion after shaking. The SC type formulation applied in the study, containing $10 \mathrm{~g}$ of BTHWA in $1 \mathrm{~L}$, was added to the working solution to get the concentrations of $20 \mathrm{mg} / \mathrm{L}, 30 \mathrm{mg} / \mathrm{L}$, and $40 \mathrm{mg} / \mathrm{L}$ BTHWA in the working solution.<smiles></smiles>

(A)<smiles>CSC(=O)c1cccc2nnsc12</smiles>

(B)<smiles></smiles>

(C)

Figure 1. Structural formulas of benzothiadiazoles derivatives selected. (A) benzo(1.2.3)thiadiazole7-carboxylic acid; (B) benzo(1.2.3)thiadiazole-7-carbothioic acid, S-methyl ester, ASM, BTH; (C) $N$-methoxy- $N$-methylbenzo(1.2.3)thiadiazole-7-carboxamide, BTHWA.

Table 1. Basic physicochemical parameters of BTHWA.

\begin{tabular}{cc}
\hline Factor & Description \\
\hline Name & $N$-methoxy- $N$-methylbenzo(1.2.3)thiadiazole-7- \\
& $\begin{array}{c}\text { carboxamide } \\
(\text { BTHWA })\end{array}$ \\
Chemical Formula & $\mathrm{C}_{9} \mathrm{H}_{9} \mathrm{~N}_{3} \mathrm{O}_{2} \mathrm{~S}$ \\
Molar mass & $223.25 \mathrm{~g} / \mathrm{moL}$ \\
Appearance & Beige crystalline powder \\
Melting point $\left({ }^{\circ} \mathrm{C}\right)$ & 125.1 \\
Solubility in water $\left(20^{\circ} \mathrm{C}\right)$ & $25 \mathrm{mg} / \mathrm{L}$ \\
\hline
\end{tabular}

\subsection{Experiment 2019}

A field experiment, including the variants of treatment presented in Table 2, was conducted at the private experimental field in Ziąbki near Bolimów in Poland $\left(52^{\circ} 11^{\prime} \mathrm{N}\right.$, $20^{\circ} 16^{\prime} \mathrm{E}, 88 \mathrm{~m}$ above sea level) from April until June of 2019, on the cultivation of strawberries var. Honeoye. The meteorological data during the experimental period were obtained from the weather station of Patoki and are shown in Tables S1 and S2. The experiment was carried out on the three-year old strawberry plants planted in 2016 on the sandy loam soil 
(pH 5.6). In this experiment, mustard was used as a forecrop and mineral fertilizers were applied in 04.2019 in the following doses: $75 \mathrm{~kg} \mathrm{~N} \mathrm{ha}^{-1}, 22 \mathrm{~kg} \mathrm{P} \mathrm{ha}^{-1}$, and $36 \mathrm{~kg} \mathrm{~K} \mathrm{ha}^{-1}$.

Table 2. The variants of treatment in the field trial on strawberries in 2019 and their abbreviations.

\begin{tabular}{cc}
\hline Abbreviation of Treatment Variant & Description of Treatment \\
\hline UTC & Untreated control \\
SFP & Standard Fungicide Program \\
$40 \times 9 / 0 \mathrm{~F}$ & BTHWA $40 \mathrm{mg} / \mathrm{L}, 9$ treatments, no fungicide treatment \\
$20 \times 9 / 0 \mathrm{~F}$ & BTHWA $20 \mathrm{mg} / \mathrm{L}, 9$ treatments, no fungicide treatment \\
$20 \times 9 / 1 \mathrm{~F}$ & BTHWA $20 \mathrm{mg} / \mathrm{L}, 9$ treatments, 1 fungicide treatment \\
$20 \times 9 / \mathrm{SFP}$ & BTHWA $20 \mathrm{mg} / \mathrm{L}, 9$ treatments, Standard Fungicide Program \\
\hline
\end{tabular}

For the experiment, a system of randomized plots was established. Each plot had an area of $7.8 \mathrm{~m}^{2}$ and on this area 26 plants with spacing $1.2 \mathrm{~m} \times 0.25 \mathrm{~m}$ were grown. To protect the cultivation against weeds, napropamide (Baristo $500 \mathrm{SC}$, dose $2.5 \mathrm{~L} \mathrm{ha}^{-1}$, 05 April 2019) was used. The experiment was performed in 6 variants of treatment, each in 4 replications (Table 2). In the untreated control object, plants were treated with the same volume of distilled water. The treatments were performed with the "Stihl SR 420" knapsack-motor sprayer with a tank capacity of $14 \mathrm{~L}$ with a pneumatic sprayer, using about $700 \mathrm{~L}$ of working fluid per $1 \mathrm{ha}$. The dates of application of BTHWA at concentrations of $20 \mathrm{mg} / \mathrm{L}$ and $40 \mathrm{mg} / \mathrm{L}$ as well as treatments with fungicides are presented in Table 3. The fruits were collected and assessed three times on 11 June 2019, 14 June 2019, and 18 June 2019, referred to as first, second and third harvest further in the text, respectively. The status of the fruit during storage was assessed every 5 days after the fruit collection on the 16 June 2019, 19 June 2019, and 23 June 2019, respectively.

Table 3. Date of application of all variants of treatment and the corresponding BBCH stage for each application in 2019.

\begin{tabular}{|c|c|c|c|c|c|c|c|c|c|}
\hline \multirow{3}{*}{$\begin{array}{l}\text { Variant of } \\
\text { Treatment }\end{array}$} & \multicolumn{9}{|c|}{ Date of Application and BВCH Scale } \\
\hline & 05.04 & 19.04 & 26.04 & 02.05 & 09.05 & 17.05 & 21.05 & 28.05 & 05.06 \\
\hline & 03 & 13 & 61 & 65 & $65 / 67$ & $65 / 67$ & 71 & 71 & $72 / 81$ \\
\hline \multicolumn{10}{|l|}{ UTC } \\
\hline SFP & & & $\mathrm{D}$ & $\mathrm{E}$ & $\mathrm{D}$ & $\mathrm{E}$ & $\mathrm{D}$ & & \\
\hline $40 \times 9 / 0 F$ & $\mathrm{~A}$ & A & A & A & A & A & A & A & A \\
\hline $20 \times 9 / 0 F$ & $\mathrm{C}$ & $\mathrm{C}$ & C & $\mathrm{C}$ & $\mathrm{C}$ & $\mathrm{C}$ & $\mathrm{C}$ & $\mathrm{C}$ & $\mathrm{C}$ \\
\hline $20 \times 9 / 1 F$ & $\mathrm{C}$ & $\mathrm{C}$ & $C+D$ & C & C & C & C & $\mathrm{C}$ & $\mathrm{C}$ \\
\hline $20 \times 9 /$ SFP & $\mathrm{C}$ & $\mathrm{C}$ & $C+D$ & $C+E$ & $C+D$ & $C+E$ & $C+D$ & $\mathrm{C}$ & $\mathrm{C}$ \\
\hline
\end{tabular}

A-BTHWA $40 \mathrm{mg} / \mathrm{L}$ (working solution from formulation $10 \mathrm{~g} / \mathrm{kg}, 1.6 \mathrm{~kg} / \mathrm{ha}$ ); C-BTHWA $20 \mathrm{mg} / \mathrm{L}$ (working solution from formulation $10 \mathrm{~g} / \mathrm{kg}, 0.8 \mathrm{~kg} / \mathrm{ha}) ; \mathrm{D}-375 \mathrm{~g} / \mathrm{kg}$ cyprodinil $+250 \mathrm{~g} / \mathrm{kg}$ fludioxonil, $0.8 \mathrm{~kg} / \mathrm{ha}$; $\mathrm{E}-250 \mathrm{~g} / \mathrm{L}$ fluopyram $+250 \mathrm{~g} / \mathrm{L}$ trifloxystrobin; $0.8 \mathrm{~L} / \mathrm{ha}$.

\subsection{Experiment 2020}

The field experiment including the variants of treatment presented in Table 4 was accomplished at the private experimental field in Dłutowo Górne in Poland $\left(52^{\circ} 29^{\prime} \mathrm{N}\right.$, $20^{\circ} 27^{\prime} \mathrm{E}, 120 \mathrm{~m}$ above sea level) from April until June of 2020 on the cultivation of strawberries var. Honeoye. The meteorological data during the experimental period were obtained from the weather station of Michałowo and are shown in Tables S3 and S4 in ESI. The experiment was carried out on the three-year old strawberry plants planted in 2017. The soil was characterized as podzolic and clayey with a $\mathrm{pH}$ of 5.8. The mustard was used as a forecrop. The mineral fertilizers were applied in 03.2020 in the following doses: $75 \mathrm{~kg} \mathrm{~N} \mathrm{ha}^{-1}, 22 \mathrm{~kg} \mathrm{P} \mathrm{ha}^{-1}$, and $36 \mathrm{~kg} \mathrm{~K} \mathrm{ha}^{-1}$. 
Table 4. The variants of treatment in the field trial on strawberries in 2020 and their abbreviations.

\begin{tabular}{cc}
\hline Abbreviation of Treatment Variant & Description of Treatment \\
\hline UTC & Untreated control \\
SFP & Standard Fungicide Program \\
$20 \times 4 / 0 \mathrm{~F}$ & BTHWA $20 \mathrm{mg} / \mathrm{L}, 4$ treatments, no fungicide treatment \\
$20 \times 4 / 1 \mathrm{~F}$ & BTHWA $20 \mathrm{mg} / \mathrm{L}, 4$ treatments, 1 fungicide treatment \\
$20 \times 4 / \mathrm{SFP}$ & BTHWA $20 \mathrm{mg} / \mathrm{L}, 4$ treatments, Standard Fungicide Program \\
$30 \times 4 / 0 \mathrm{~F}$ & BTHWA $30 \mathrm{mg} / \mathrm{L}, 4$ treatments, no fungicide treatment \\
$30 \times 4 / 1 \mathrm{~F}$ & BTHWA $30 \mathrm{mg} / \mathrm{L}, 4$ treatments, 1 fungicide treatment \\
$30 \times 4 / \mathrm{SFP}$ & BTHWA $30 \mathrm{mg} / \mathrm{L}, 4$ treatments, Standard Fungicide Program \\
\hline
\end{tabular}

In the experiment, the system of randomized plots was used. Each plot had an area of $9.62 \mathrm{~m}^{2}$ and on this area 26 plants with spacing $1.48 \mathrm{~m} \times 0.5 \mathrm{~m}$ were cultivated. To protect the cultivation against insects, acetamiprid (Mospilan 20 SP, dose $0.2 \mathrm{~kg} \mathrm{ha}^{-1}, 10$ May 2020) was used. The experiment was performed in 8 variants of treatment in 4 replications (Table 4). In control object plants were treated with the same volume of distilled water. The treatments were performed with the "Stihl SR 420" knapsack-motor sprayer with a tank capacity of 141 with a pneumatic sprayer, using about $700 \mathrm{~L}$ of working fluid per 1 ha. The dates of application of BTHWA substance at a concentration of $20 \mathrm{mg} / \mathrm{L}$ and $30 \mathrm{mg} / \mathrm{L}$ and treatments with fungicides are presented in Table 5 . The fruits were collected and assessed three times on 18 June 2020, 22 June 2020, and 25 June 2020, referred to as first, second, and third harvest further in the text, respectively. The health status of the fruit during storage was assessed every 5 days after the fruit collection on the 23 June 2020, 27 June 2020, and 30 June 2020, respectively.

Table 5. Date of application of all variants of treatment and the corresponding BBCH stage for each application in 2020 .

\begin{tabular}{ccccccc}
\hline \multirow{2}{*}{$\begin{array}{c}\text { Variant of } \\
\text { Treatment }\end{array}$} & $\mathbf{3 0 . 0 4}$ & $\mathbf{1 3 . 0 5}$ & $\mathbf{2 1 . 0 5}$ & $\mathbf{2 9 . 0 5}$ & $\mathbf{0 4 . 0 6}$ & $\mathbf{1 0 . 0 6}$ \\
& $\mathbf{5 6}$ & $\mathbf{6 1}$ & $\mathbf{6 5}$ & $\mathbf{6 7}$ & $\mathbf{8 1}$ & $\mathbf{8 1}$ \\
\hline $\mathrm{UTC}$ & & & & & \\
$\mathrm{SFP}$ & & $\mathrm{D}$ & $\mathrm{E}$ & $\mathrm{D}$ & $\mathrm{E}$ & $\mathrm{D}$ \\
$20 \times 4 / 0 \mathrm{~F}$ & $\mathrm{C}$ & $\mathrm{C}$ & & $\mathrm{C}$ & & $\mathrm{C}$ \\
$20 \times 4 / 1 \mathrm{~F}$ & $\mathrm{C}$ & $\mathrm{C}+\mathrm{E}$ & & $\mathrm{C}$ & & $\mathrm{C}$ \\
$20 \times 4 / \mathrm{SFP}$ & $\mathrm{C}$ & $\mathrm{C}+\mathrm{D}$ & $\mathrm{E}$ & $\mathrm{C}+\mathrm{D}$ & $\mathrm{E}$ & $\mathrm{C}+\mathrm{D}$ \\
$30 \times 4 / 0 \mathrm{~F}$ & $\mathrm{~B}$ & $\mathrm{~B}$ & & $\mathrm{~B}$ & & $\mathrm{~B}$ \\
$30 \times 4 / 1 \mathrm{~F}$ & $\mathrm{~B}$ & $\mathrm{~B}+\mathrm{E}$ & & $\mathrm{B}$ & & $\mathrm{B}$ \\
$30 \times 4 / \mathrm{SFP}$ & $\mathrm{B}$ & $\mathrm{B}+\mathrm{D}$ & $\mathrm{E}$ & $\mathrm{B}+\mathrm{D}$ & $\mathrm{E}$ & $\mathrm{B}+\mathrm{D}$ \\
\hline
\end{tabular}

B-BTHWA $30 \mathrm{mg} / \mathrm{L}$ (working solution from formulation $10 \mathrm{~g} / \mathrm{kg}, 1.2 \mathrm{~kg} / \mathrm{ha}$ ); C-BTHWA $20 \mathrm{mg} / \mathrm{L}$ (working solution from formulation $10 \mathrm{~g} / \mathrm{kg}, 0.8 \mathrm{~kg} / \mathrm{ha}$ ); D-375 g/ $\mathrm{kg}$ cyprodinil $+250 \mathrm{~g} / \mathrm{kg}$ fludioxonil; $0.8 \mathrm{~kg} / \mathrm{ha}$; $\mathrm{E}-250 \mathrm{~g} / \mathrm{L}$ fluopyram $+250 \mathrm{~g} / \mathrm{L}$ trifloxystrobin; $0.8 \mathrm{~L} / \mathrm{ha}$.

\subsection{Plant Size}

Plant area size was determined during the 1st harvest by measuring the diameter and height of 10 plant's canopy in each of 4 replications $(4 \times 10 /$ variant of treatment $)$ exactly to $1 \mathrm{~mm}$ with a side caliper. Then the averaged diameter values were calculated, according to the formula for the area of the circle (surface area $=\pi \cdot \mathrm{r}^{2}$ ), to the plant surface. Plant volume was calculated from the cone volume formula, $\mathrm{V}=1 / 3 \cdot \pi \cdot \mathrm{r}^{2} \cdot \mathrm{H}$, where $\mathrm{r}$ is the radius and $\mathrm{H}$ is the height.

\subsection{Storage Stability}

From each of four replications, 100 visually healthy fruits $(4 \times 100 /$ variant of treatement) were stored in humidity within the range of $92-95 \% \mathrm{RH}$ at $5{ }^{\circ} \mathrm{C}$ for 5 days. Subsequently, all infected fruits were assessed. The results are shown as the number of infected fruits per 100 visually healthy fruits taken for storage. 


\subsection{Assessment of Fruit Health in the Field and during Storage}

The biological effectiveness of all variants of treatment in strawberry protection was assessed after each harvest by the number of total infected strawberry fruit (percentage of infected fruits compared to all fruit harvested) on 26 plants per plot in 4 replicates compared to controls (untreated plants) and standard measures. The fruits were assessed visually towards following pathogens: Botrytis cinerea, Colletotrichum sp., Phytophthora sp., and Rhizopus stolonifer.

In order to assess the influence of BTHWA and fungicides on the storage stability, 100 visually healthy fruits $(4 \times 100$ /variant of treatment $)$ were stored from each replicate, and their health status was assessed on the 5 th day of storage at $5{ }^{\circ} \mathrm{C}$. The assessment was carried out by counting all infected fruits per 100 fruits harvested from the plot and comparing the number to that of infected fruits from the Untreated control (UTC) and Standard Fungicide Program (SFP).

\subsection{The Firmness of Fruits}

The fruits from the first harvest were subjected to measurement one day following the harvest. Until measurement, the fruits were stored at $5{ }^{\circ} \mathrm{C}$. The firmness of strawberries was expressed as the force required to pierce the skin of the fruit with a $3.2 \mathrm{~mm}$ diameter flat mandrel moving at a speed of $50 \mathrm{~mm} / \mathrm{min}$. Measurements were carried out with an Instron 4303 tensile-testing machine (Instron Ltd., High Wycombe, UK) equipped with a measuring head $(10 \mathrm{~N})$. Results were expressed in Newtons $(\mathrm{N})$. The evaluation of fruit firmness was carried out on the side surface at the height of the largest diameter of the sample of 30 fruits from the variant of treatment.

\subsection{The Measurement of Color}

The fruits from the first harvest were subjected to measurement one day following harvest. Until measurement, the fruits were stored at $5{ }^{\circ} \mathrm{C}$. The measurement of color was performed using the spectrophotometric method with a CM-2600d portable spectrometer (Konica Minolta Sensing Inc., Osaka, Japan). Measurements were made for a D65 light source using a measuring mesh with a diameter of $3 \mathrm{~mm}$ and an optical observer position of $10^{\circ}$. Color was instrumentally measured for 30 fruits from each variant of treatment, collected during the first harvest. The measurement of color parameters were expressed in the color units directly measured by the instrument: $L^{*}$ (darkness/lightness), $\mathrm{a}^{*}$ (green/red), and $b *$ (blue/yellow).

\subsection{Total Soluble Solids (TSSs)}

Total soluble solids content was measured with an Atago Refractometer RX-7000CX (Atago, Saitamam, Japan) at standardized temperature $\left(20^{\circ} \mathrm{C}\right)$ in fruit juices obtained by manually pressing $100 \mathrm{~g}$ of fruits from each replication (4/variant of treatment). Fruits were collected on 30 June 2020. Values are expressed as refractometric TSS (Brix).

\subsection{Fresh and Dry Weight}

Fresh and dry weight of fruits was determined by weighing. From each of the 4 replications, $100 \mathrm{~g}$ of fresh fruits were collected on 30 June 2020 and weighted. Subsequently, fruits were dried for $24 \mathrm{~h}$ at $50{ }^{\circ} \mathrm{C}$, and then at $105^{\circ} \mathrm{C}$ until constant mass.

\subsection{Determination of the Content of Ascorbic Acid}

To determine the content of L-ascorbic acid in strawberry fruits, the following procedure was used: $1 \mathrm{~kg}$ of fresh fruits was collected from each variant of treatment during the first harvest, then the fruits were destemmed and frozen. Subsequently, the samples were crushed in dry ice. Extraction from the complied sample was performed with $6 \%$ $\mathrm{HPO}_{3}$. The content of L-ascorbic acid was determined by high performance liquid chromatography (Agilent 1200 HPLC system, equipped with a DAD detector, Santa Clara, CA, USA). The separation was carried out using Supelco LC-18 columns with following elution 
conditions: speed $0.8 \mathrm{~mL} / \mathrm{min}$, temperature $30{ }^{\circ} \mathrm{C}$, wavelength $244 \mathrm{~nm}$, mobile phase- $1 \%$ phosphate buffer $\left(\mathrm{KH}_{2} \mathrm{PO}_{4}\right)$ at $\mathrm{pH}=2.5$ in isocratic flow. The results are expressed in $\mathrm{mg} / 100 \mathrm{~g}$ of fruits.

\subsection{Determination of the Content of Phenolic Compounds}

One kilogram of fresh fruits representing each variant of treatment, collected during the first harvest, was destemmed and frozen. Subsequently, the samples were crushed in dry ice. The total content of phenolic compounds was determined by the modified spectrophotometric method using the Folin-Ciocalteau reagent [38]. The absorbance of the extract was measured at a wavelength of $765 \mathrm{~nm}$ in comparison to a blank sample. The results are expressed as $\mathrm{mg}$ gallic acid per $100 \mathrm{~g}$ of fruits.

\subsection{Determination of the Content of Anthocyanin Compounds}

Anthocyanin content was determined from $1 \mathrm{~kg}$ of fresh fruits collected from each variant of treatment at the first harvest using the $\mathrm{pH}$ differential method: with an UV/Vis CARY 300E spectrophotometer (Varian) according to Giusti and Wrolstad [39]. A sample of the fruits ground in dry ice was mixed with $100 \mathrm{~mL}$ of a mixture of ethanol and hydrochloric acid (150 mL of $1.5 \mathrm{M} \mathrm{HCl}$ solution in $1 \mathrm{~L}$ of ethanol) and homogenized for $2 \mathrm{~min}$ using an IKA homogenizer (Ultra Turrax ${ }^{\circledR}$ T25 basic IKA-WERKE, Staufen, Germany). Subsequently, the sample was centrifuged at $3000 \mathrm{rpm}$ for $10 \mathrm{~min}$. The extract was diluted in $10 \mathrm{~mL} \mathrm{of} \mathrm{pH}$ 1.0 buffer $(\mathrm{KCl}$ in $\mathrm{HCl}$ ) and $10 \mathrm{~mL}$ of $\mathrm{pH} 4.5$ buffer (dehydrated sodium acetate in $\mathrm{HCL}$ ), then stirred and left for $1 \mathrm{~h}$ and protected against light. The absorbance measurement was carried out at a wavelength of $520 \mathrm{~nm}$. The content of anthocyanins was calculated on the basis of the molar absorbance of glucoside-3-pelargonidine (22400) and the molar mass $-433.2 \mathrm{~g} / \mathrm{moL}$. The results are expressed in $\mathrm{mg} / 100 \mathrm{~g}$ of fruits.

\subsection{Fruit Respiration}

Fruit gas exchange was measured using a portable infrared gas analyzer coupled to a fruit chamber (LCpro+, ADC, Hoddesdon, UK). The chamber volume was $1 \mathrm{~L}$ with a flow rate of $200 \mathrm{~mL} \mathrm{~min}^{-1}$. The measurements were taken $24 \mathrm{~h}$ after harvest at $10{ }^{\circ} \mathrm{C}$.

\subsection{Statistical Analysis}

Statistical significance of the effect of the treatments on the: marketable, non-marketable, and total yield; mean weight of marketable fruit; diseases development of fruit in the field and during storage; physicochemical parameters of fruit including content of anthocyans, polyphenols, ascorbic acid, firmness, color, dry weight, ${ }^{\circ}$ Brix, and respiration rate; the plant size was assessed with an ANOVA. Differences between the mean values were estimated with the Newman-Keuls test at the significance level of $p=0.05$. In 2019, the analysis was performed for single-factor experiments in 4 replications. However, in 2020, due to the change in the experimental arrangement, a statistical analysis was performed for two-factor experiments in 4 replications with two separate control groups (UTC-untreated control and SFP_standard fungicide program). The significance of the differences in the mean values from two-factor analysis and the control variants of treatment was determined on the basis of the LSD test. The Pearson's correlation coefficients between the applied level of treatments and measured parameters as well as between all measured parameters were calculated.

\section{Results}

\subsection{Overview of the Experiments}

As BTHWA has been hitherto studied in model systems, the aim of the first field experiment performed in 2019 was to verify if the expected impact of BTHWA in the field would be the same as that observed in less complex model experiments. Another objective was to check the effects of BTHWA on the plants treated with the commonly used fungicides applied in two variants (a single application and full standard program). The 
results obtained in 2019 forced a verification and modification of the plan of the experiment performed in 2020. In 2019, the plant size changes dependent on the applied dose of BTHWA were observed. As a result of application of too high cumulative dose of BTHWA $(40 \times 9 / 0 \mathrm{~F})$, resulted from too high concentration or to many treatments, the plant growth was reduced, which was in agreement with the growth-immunity tradeoff postulate [11]. On the other hand, the plants treated with a lower dose of BTHWA $(20 \times 9 / 0 \mathrm{~F})$ were found to be of greater size than the untreated controls. The observations made in 2019 provided the grounds for putting forward the hypothesis that a proper adjustment of the treatment mode (concentration of BTHWA and number of applications) may have a stimulating effect on the plants growth even in unfavorable weather conditions such as limited rainfall period that occurred in 2019. In such conditions, it was expected to observe a pronounced effect of the plant metabolism switching after treatments to induction of resistance, despite a low pathogen pressure, leading to reduction of the yield or plant growth. The differences were not as significant as expected, moreover, application of a lower dose stimulated the plant growth. Moreover, analysis of the other parameters measured in 2019 revealed no significant differences in their values between the plants treated with the BTHWA dose of $40 \mathrm{mg} / \mathrm{L}(40 \times 9 / 0 \mathrm{~F})$ and $20 \mathrm{mg} / \mathrm{L}(20 \times 9 / 0 \mathrm{~F})$.

In view of the above and own field experience, in 2020 the number of treatments was reduced and the intervals between them were increased from 7 to approximately 14 days [40]. Moreover, the higher dose of BTHWA was reduced from 40 to $30 \mathrm{mg} / \mathrm{L}$ and the number of parameters determined to characterize the effect of the treatments were extended. This modification was introduced in order to verify the hypothesis that the choice of a suitable dose of the resistance inducer and the frequency of the doses application would bring the effect of stimulating the plant growth. The experiment in 2020 was supplemented with the studies aimed at checking the interaction between the effects of BTHWA and fungicides, the latter applied in two variants (single dose and full standard program). In order to get a deeper insight into the impact of the variants of treatment applied on the strawberries yield, the intensity of respiration of strawberry fruit in the period of storage was also measured.

\subsection{Weather Conditions}

Detailed data on the weather conditions in the periods of the experiments performed in 2019 and 2020 are shown in Tables S1 and S3 in ESI. A simplified version of the accumulated rainfall is presented in Figure 2. To compare variations in the rainfall distribution, which is an important factor while assessing disease development, "day 0" was chosen as the beginning of flowering. In general, the weather conditions in 2019 were not favorable for pathogen development, while in 2020 the opposite was the case. A comparison of rainfall accumulation in the seasons of the experiments of 2019 and 2020 shows significant differences. Of particular importance is the difference in rainfalls from two weeks before flowering to three weeks after flowering. The total amount of rainfall in 2020 was $64.8 \mathrm{~mm}$, as opposed to just $13.4 \mathrm{~mm}$ in 2019. The low amount of rainfall in 2019 resulted in lower pathogen pressure, a decrease in the total yield of strawberries, but also a higher content of polyphenols in the fruit. Moreover, the period from flowering to the first harvest in 2019 was 46 days, and in 2020 it was only 36 days, despite the fact that the flowering in 2020 began two weeks later than in 2019 . 


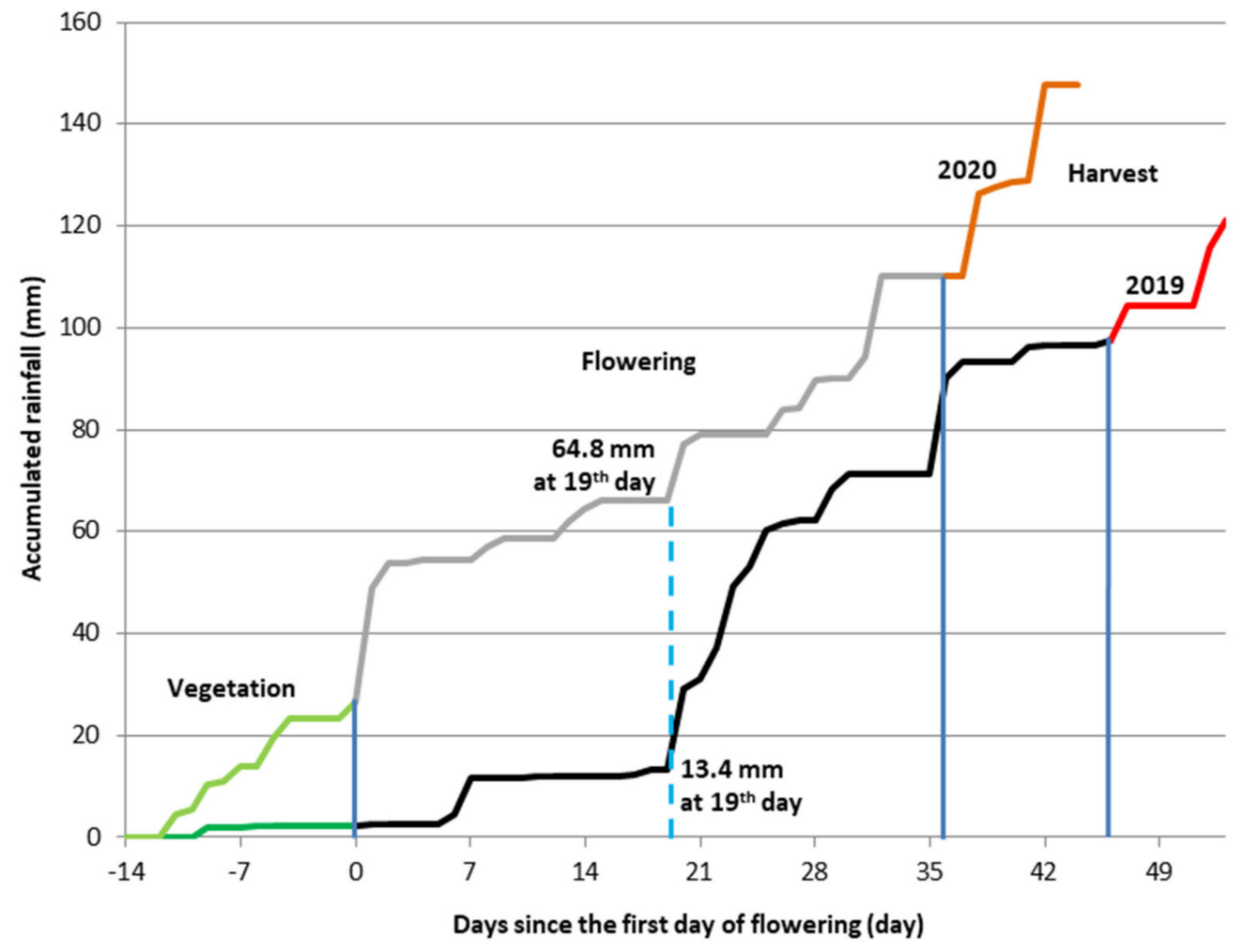

Figure 2. Distribution and sum of rainfall on the experimental plots in 2019 and 2020. Point 0 marks the beginning of lowering.

\subsection{Experiment 2019}

\subsubsection{The Plant Size}

Statistical analysis of the parameters describing the size of strawberry plants showed no significant differences between the experiments in variant UTC and variant SFP (Table 6). Treatment according to variants $20 \times 9 / 0 \mathrm{~F}$ and $40 \times 9 / 0 \mathrm{~F}$ also did not result in significant differences. A significant increase in plant height was observed only for the treatment in variant $20 \times 9 / 1 \mathrm{~F}$. Moreover, the plants treated according to variant $20 \times 9 / 0 \mathrm{~F} \mathrm{had}$ the highest surface area and volume of all plants treated in all variants; however, these differences were not significant. The results obtained were so surprising that it was decided to pay attention to the changes in these parameters in 2020.

Table 6. One-way analysis of the effects on selected parameters of plant size of all variants of treatment tested in 2019 (as described in Table 2).

\begin{tabular}{ccccccc}
\hline \multirow{2}{*}{ Parameter } & \multicolumn{7}{c}{ Variant of Treatment } \\
\cline { 2 - 7 } & UTC & SFP & $\mathbf{4 0} \times \mathbf{9 / 0 F}$ & $\mathbf{2 0} \times \mathbf{9 / 0 F}$ & $\mathbf{2 0} \times \mathbf{9 / 0 F}$ & $\mathbf{2 0} \times \mathbf{9 / S F P}$ \\
\hline Height $(\mathrm{cm})$ & $27.85 \mathrm{a}$ & $28.18 \mathrm{a}$ & $27.88 \mathrm{a}$ & $28.62 \mathrm{a}$ & $30.42 \mathrm{~b}$ & $27.98 \mathrm{a}$ \\
Diameter $(\mathrm{cm})$ & 28.44 & 27.42 & 26.38 & 28.95 & 27.74 & 27.51 \\
Plant area $\left(\mathrm{cm}^{2}\right)$ & 648.1 & 606.2 & 599.4 & 677.3 & 615.8 & 628.2 \\
Volume $\left(\mathrm{dm}^{3}\right)$ & 6.007 & 5.6286 & 5.7149 & 6.4602 & 6.249 & 5.933 \\
\hline
\end{tabular}

Symbols for the table: within rows, mean values marked with the same letter do not differ significantly at $p=0.05$, while mean values are not marked with a letter if differences are not significant. Shadowed columns indicate reference variants of treatment.

\subsubsection{The Yield}

Regardless of the variant of treatment, no differences were found in the total yield (Table 7). No negative effect of the use of BTHWA on the total yield and marketable yield was found, while expressing these parameters in kilograms of fruits per square meter and the number of fruits per square meter. 
Table 7. One-way analysis of the effects on selected parameters of yield of all variants of treatment tested in 2019 (as described in Table 2).

\begin{tabular}{|c|c|c|c|c|c|c|}
\hline \multirow{2}{*}{ Parameter } & \multicolumn{6}{|c|}{ Variant of Treatment } \\
\hline & UTC & SFP & $40 \times 9 / 0 F$ & $20 \times 9 / 0 F$ & $20 \times 9 / 0 F$ & $20 \times 9 /$ SFP \\
\hline Marketable yield (pcs. $/ \mathrm{m}^{2}$ ) & 52.6 & 56.03 & 63.11 & 58.24 & 59.71 & 56.31 \\
\hline Non-marketable yield (pcs. $/ \mathrm{m}^{2}$ ) & 0.032 & 0.032 & 0.032 & 0.0641 & 0.032 & 0 \\
\hline Total yield $\left(\mathrm{pcs} . / \mathrm{m}^{2}\right)$ & 52.63 & 56.06 & 63.14 & 58.3 & 59.74 & 56.31 \\
\hline Marketable yield $\left(\mathrm{kg} / \mathrm{m}^{2}\right)$ & 0.0004 & 0.0004 & 0.0004 & 0.0007 & 0.0004 & 0 \\
\hline Non-marketable yield $\left(\mathrm{kg} / \mathrm{m}^{2}\right)$ & 0.4171 & 0.4379 & 0.5184 & 0.4667 & 0.5206 & 0.4535 \\
\hline Total yield $\left(\mathrm{kg} / \mathrm{m}^{2}\right)$ & 7.91 & 7.85 & 8.29 & 8.14 & 8.75 & 8.06 \\
\hline Mean weight of marketable fruit $(\mathrm{g})$ & 52.6 & 56.03 & 63.11 & 58.24 & 59.71 & 56.31 \\
\hline
\end{tabular}

Symbols for the table: within rows, mean values marked with the same letter do not differ significantly at $p=0.05$, while mean values are not marked with a letter if differences are not significant. The parameter expressed in $\left(\mathrm{pcs} . / \mathrm{m}^{2}\right)$ mean values the number of fruit pieces included in the given parameter per $1 \mathrm{~m}^{2}$ of the plot of the given variant of treatment. Shadowed columns indicate reference variants of treatment.

\subsubsection{Plant Infections in the Field and During Storage}

The weather conditions and low pathogen pressure in 2019 prevented the strawberry fruits from being affected by diseases, which was particularly evident after assessment of fruits from the plants of variants UTC and SFP (Table 8). No significant differences were found in non-marketable yield and the presence of pathogens on fruits assessed during a field trial. Moreover, evaluation of storage capability of strawberry fruits showed only lower infestation of fruits by Botrytis cinerea in fruits from the plants treated according to variant SFP. The treatments according to the other variants resulted in lower infestation of fruits by Botrytis cinerea comparing to variant UTC; however, the differences were not confirmed.

Table 8. One-way analysis of the effects on parameters related to pathogens development, in the field conditions, and during storage, of all variants of treatment tested in 2019 (as described in Table 2).

\begin{tabular}{|c|c|c|c|c|c|c|}
\hline \multirow{2}{*}{ Parameter } & \multicolumn{6}{|c|}{ Variant of Treatment } \\
\hline & UTC & SFP & $40 \times 9 / 0 F$ & $20 \times 9 / 0 F$ & $20 \times 9 / 0 F$ & $20 \times 9 /$ SFP \\
\hline \multicolumn{7}{|l|}{ FIELD } \\
\hline Botrytis cinerea $\left(\mathrm{pcs} . / \mathrm{m}^{2}\right)$ & 0 & 0.032 & 0 & 0 & 0.032 & 0 \\
\hline Phytophtora sp. (pcs. $\left./ \mathrm{m}^{2}\right)$ & 0 & 0 & 0 & 0 & 0 & 0 \\
\hline Colletotrichum $\mathrm{sp} .\left(\mathrm{pcs} . / \mathrm{m}^{2}\right)$ & 0 & 0 & 0 & 0 & 0 & 0 \\
\hline Rhizopus stolonifer (pcs./ $/ \mathrm{m}^{2}$ ) & 0.032 & 0 & 0.032 & 0.0641 & 0 & 0 \\
\hline Botrytis cinerea $(\%)$ & 0 & 0.0608 & 0 & 0 & 0.047 & 0 \\
\hline Phytophtora sp. (\%) & 0 & 0 & 0 & 0 & 0 & 0 \\
\hline Colletotrichum sp. (\%) & 0 & 0 & 0 & 0 & 0 & 0 \\
\hline Rhizopus stolonifer (\%) & 0.062 & 0 & 0.0408 & 0.0938 & 0 & 0 \\
\hline Fruits Infected (\%) & 0.062 & 0.0608 & 0.0408 & 0.0938 & 0.047 & 0 \\
\hline \multicolumn{7}{|l|}{ STORAGE } \\
\hline Botrytis cinerea (\%) & $1.4166 \mathrm{~b}$ & $0.25 \mathrm{a}$ & $0.8333 a b$ & $0.6666 \mathrm{ab}$ & $1.0833 \mathrm{ab}$ & $0.4166 \mathrm{ab}$ \\
\hline Phytophtora sp. (\%) & 0 & 0 & 0 & 0 & 0 & 0 \\
\hline Colletotrichum sp. (\%) & 0.1667 & 0 & 0 & 0.0833 & 0.5 & 0.0833 \\
\hline Rhizopus stolonifer (\%) & 0.0833 & 0.5833 & 0.8333 & 0.4167 & 0 & 0.1667 \\
\hline Fruits infected (\%) & 1.6667 & 0.8334 & 1.6667 & 1.1667 & 1.5833 & 0.6667 \\
\hline
\end{tabular}

Symbols for the table: within rows, mean values marked with the same letter do not differ significantly at $p=0.05$, while mean values are not marked with a letter if differences are not significant. Parameter expressed in (\%) mean values the number of fruit pieces included in a given parameter per 100 fruits within a plot of a given variant of treatment. Shadowed columns indicate reference variants of treatment.

\subsubsection{Physicochemical Parameters}

The treatment of plants according to the variant SFP resulted in a significant increase in the content of anthocyanins and a decrease in the content of ascorbic acid compared to the UTC variant (Table 9). The content of anthocyanin increased significantly as a result of 
treatment in variant SFP comparing to that in the plants of variant UTC. As a result of the treatment of plants in variant $20 \times 9 / 0 \mathrm{~F}$, the content of anthocyanins increased more than as a result of the treatment in variant SFP, and reached the highest value among all variants of treatment. However, as the BTHWA dose increased from $20 \mathrm{mg} / \mathrm{L}$ used in variant $20 \times 9 / 0 \mathrm{~F}$ to $40 \mathrm{mg} / \mathrm{L}$ used in variant $40 \times 9 / 0 \mathrm{~F}$, the anthocyanins content decreased to the level obtained in the fruits of the plants of variant UTC. No significant differences were found in polyphenol content and firmness of the fruit.

Table 9. One-way analysis of the effect on selected physicochemical parameters of fruits of all variants of treatment tested in 2019 (as described in Table 2).

\begin{tabular}{|c|c|c|c|c|c|c|}
\hline \multirow{2}{*}{ Parameter } & \multicolumn{6}{|c|}{ Variant of Treatment } \\
\hline & UTC & SFP & $40 \times 9 / 0 F$ & $20 \times 9 / 0 F$ & $20 \times 9 / 0 F$ & $20 \times 9 / S F P$ \\
\hline Anthocyans (mg/100 g of fruits) & $57.82 \mathrm{a}$ & $62.94 \mathrm{~b}$ & $56.45 \mathrm{a}$ & $68.84 \mathrm{c}$ & $61.22 \mathrm{~b}$ & $61.22 \mathrm{~b}$ \\
\hline Polyphenols (mg/100 g of fruits) & 385.4 & 390.4 & 389.4 & 397.3 & 372.3 & 393.9 \\
\hline Ascorbic acid (mg/100 g of fruits) & $63.8 \mathrm{~d}$ & $58.72 \mathrm{c}$ & $56.1 \mathrm{~b}$ & $55.06 \mathrm{ab}$ & $54.58 \mathrm{a}$ & $63.21 \mathrm{~d}$ \\
\hline Firmness $(\mathrm{N})$ & 1.1230 & 1.1717 & 1.0550 & 1.0730 & 1.0720 & 0.8433 \\
\hline Fruit color-L (darkness/lightness) & $36.97 \mathrm{c}$ & $35.87 \mathrm{bc}$ & 33.66 a & $35.78 \mathrm{bc}$ & $36.12 \mathrm{bc}$ & $33.48 \mathrm{a}$ \\
\hline Fruit color-a (green/red) & $15.24 \mathrm{ab}$ & $15.03 \mathrm{ab}$ & $16.44 \mathrm{ab}$ & $14.15 \mathrm{a}$ & $21.93 c$ & $18.09 \mathrm{~b}$ \\
\hline Fruit color-b (blue/yellow) & 11.73 & 11.61 & 11.40 & 10.28 & 14.67 & 11.04 \\
\hline
\end{tabular}

Symbols for the table: within rows, mean values marked with the same letter do not differ significantly at $p=0.05$, while mean values are not marked with a letter if differences are not significant. Shadowed columns indicate reference variants of treatment.

The content of ascorbic acid in the fruit treated according to variant SFP decreased significantly comparing to those in variant UTC. The treatment of plants in variants $20 \times 9 / 0 \mathrm{~F}$ and $20 \times 9 / 1 \mathrm{~F}$ reduced the ascorbic acid content below the value obtained for the plants treated according to variant SFP and led to the lowest values of ascorbic acid content in plants treated in all variants. The plant treatment in variant $20 \times 9 / \mathrm{SFP}$ resulted in the ascorbic acid content at the same level as that achieved in the plants of variant UTC, and these values were the highest in the plants treated in all variants.

The lowest value of the color parameter, L, was shown by the fruits from the plants treated in variant $40 \times 9 / 0 \mathrm{~F}$ and variant $20 \times 9 / \mathrm{SFP}$, and only these fruits differed significantly in the color parameter, L, from the fruits of the plants of variants UTC and SFP. All variants of treatment resulted in a positive value of the color parameter, a, which indicates the greater proportion of red, not green. The color of fruits from the plants treated in variant $20 \times 9 / 1 \mathrm{~F}$ had the highest proportion of red color, and only this variant had a significantly higher proportion of red color compared to the fruit of plants of variants UTC and SFP. The lowest value of the color parameter, a, was noticed for the fruit of from the plants treated in variant $20 \times 9 / 0 \mathrm{~F}$. The color parameter, $b$, obtained for fruits of plants treated according to all variants also had a positive value, which indicates the proportion of yellow, not green, in the $\mathrm{L}^{*} \mathrm{a}{ }^{*} \mathrm{~b}$ * space. However, no significant differences in this parameter were found.

\subsection{Experiment 2020}

\subsubsection{The Plant Size}

Results of the study carried out in 2020 showed no significant differences in plant size parameters between the plant of variant UTC and SFP. However, a significant effect of the use of BTHWA (treatment in variants $20 \times 4 / 0 \mathrm{~F}$ and $30 \times 4 / 0 \mathrm{~F}$ ) on the parameters describing the plant size were noted (Tables 10 and 11). 
Table 10. Two-way analysis of the effects on selected parameters of plant size of all variants of treatment tested in 2020.

\begin{tabular}{|c|c|c|c|c|c|}
\hline & \multirow{2}{*}{ BTHWA } & \multicolumn{3}{|c|}{ Type of Fungicide Treatment } & \multirow{2}{*}{ Mean } \\
\hline & & $\mathbf{0 F}$ & $1 F$ & SFP & \\
\hline \multirow{3}{*}{ Height (cm) } & $20 \times 4$ & $25.78 \mathrm{~b}^{\circ}$ & $24.39 \mathrm{a}$ & $23.90 \mathrm{a}$ & 24.69 \\
\hline & $30 \times 4$ & $26.70 b^{* 0}$ & $23.91 \mathrm{a}$ & $22.70 \mathrm{a}^{*}$ & 24.44 \\
\hline & Mean & $26.24 \mathrm{~B}^{* 0}$ & $24.15 \mathrm{~A}$ & $23.30 \mathrm{~A}$ & \\
\hline \multirow{3}{*}{$\begin{array}{l}\text { Diameter } \\
\quad(\mathrm{cm})\end{array}$} & $20 \times 4$ & $28.46 b^{* \circ}$ & $27.50 \mathrm{~b}^{* \circ}$ & $25.36 \mathrm{a}^{*}$ & $27.11 * \circ$ \\
\hline & $30 \times 4$ & $28.60 b^{* \circ}$ & $25.49 \mathrm{a}^{*}$ & $25.11 \mathrm{a}^{*}$ & $26.40 * 0$ \\
\hline & Mean & $28.53 C^{* 0}$ & $26.49 \mathrm{~B}^{* 0}$ & $25.24 \mathrm{~A}^{*}$ & \\
\hline \multirow{3}{*}{$\begin{array}{l}\text { Plant area } \\
\qquad\left(\mathrm{cm}^{2}\right)\end{array}$} & $20 \times 4$ & $649.0 \mathrm{~b}^{* \circ}$ & $604.7 b^{* 0}$ & $515.3 a^{*}$ & $589.6 * 0$ \\
\hline & $30 \times 4$ & $653.4 b^{* \circ}$ & $520.0 a^{*}$ & $501.4 \mathrm{a}$ & $558.3 * 0$ \\
\hline & Mean & $651.2 C^{* 0}$ & $562.3 \mathrm{~B}^{* 0}$ & $508.3 \mathrm{~A}^{*}$ & \\
\hline \multirow{3}{*}{$\begin{array}{l}\text { Volume } \\
\left(\mathrm{dm}^{3}\right)\end{array}$} & $20 \times 4$ & $5.681 \mathrm{~cd}^{* 0}$ & $4.975 \mathrm{bc}^{* 0}$ & $4.185 \mathrm{ab}$ & $4.947 * \circ$ \\
\hline & $30 \times 4$ & $5.959 \mathrm{~d}^{* \circ}$ & $4.222 \mathrm{ab}$ & $3.804 \mathrm{a}$ & $4.662 * \circ$ \\
\hline & Mean & $5.820 C^{* \circ}$ & $4.599 \mathrm{~B}^{* 0}$ & $3.995 \mathrm{~A}$ & \\
\hline
\end{tabular}

Factors in the columns marked as $0 \mathrm{~F}, 1 \mathrm{~F}$, and SFP mean increasing amounts of fungicide treatments, while in rows factors marked as $20 \times 4$ and $30 \times 4$ mean increasing concentration of BTHWA (as described in Table 4). Symbols for the table: separately for rows and columns, mean values marked with the same capital letters do not differ significantly at $p=0.05$, while mean values that do not differ significantly are not marked with letter; within rows and columns, mean values marked with the same small letters do not differ significantly at $p=0.05$, while mean values that do not differ significantly are not marked with letter; *-denotes significant difference comparing to untreated control (UTC) (Table 11); ${ }^{\circ}$ - denotes a significant difference comparing to treatment with standard fungicide program (SFP) (Table 11).

Table 11. Separate control groups for Table 10 presenting the effect on selected parameters of plant size of variants UTC (untreated control) and SFP (standard fungicide program) in 2020.

\begin{tabular}{ccc}
\hline \multirow{2}{*}{ Parameter } & \multicolumn{2}{c}{ Variant of Treatment } \\
\cline { 2 - 3 } & UTC & SFP \\
\hline Height $(\mathrm{cm})$ & 24.55 & 23.85 \\
Diameter $(\mathrm{cm})$ & 23.53 & 24.39 \\
Plant area $\left(\mathrm{cm}^{2}\right)$ & 444.01 & 474.03 \\
Volume $\left(\mathrm{dm}^{3}\right)$ & 3.72 & 3.81 \\
\hline Symbors & . &
\end{tabular}

Symbols for the table: separately for rows, mean values marked with different Greek letters differs significantly at $p=0.05$, while mean values that do not differ significantly are not marked with letter. Shadowed columns indicate reference variants of treatment.

The height of plants treated according to variants $20 \times 4 / 0 \mathrm{~F}$ and $30 \times 4 / 0 \mathrm{~F}$ were significantly taller than those treated in the other variants. Contrarily, the height of the plants treated according to variant $30 \times 4$ /SFP was significantly shorter than that of the plants of variant UTC.

The diameters of the strawberry plants treated in variants $20 \times 4 / 0 \mathrm{~F}, 30 \times 4 / 0 \mathrm{~F}$, and $20 \times 4 / 1 \mathrm{~F}$ were significantly greater than those of the plants treated in the other variants. No significant differences were observed as a result of the treatments in variant $20 \times 4 / 0 \mathrm{~F}$ and variant $30 \times 4 / 0 \mathrm{~F}$, with increased dose of BTHWA. The diameters of the strawberry plants treated in variant $30 \times 4 /$ SFP were the lowest.

Similar relations between the results of different treatment variants were also noted for the plant area and plant volume. Analysis of the mean values of the plant volume showed that the use of BTHWA alone (mean parameter value obtained for treatment variants $20 \times 4 / 0 \mathrm{~F}$ and $30 \times 4 / 0 \mathrm{~F}$ ) resulted in the increase in plant volume by $56.5 \%$ compared to that of the plants of variant UTC and by $52.8 \%$ compared to that of the plants treated in variant SFP. In addition, the combined use of one fungicide treatment in combination with BTHWA (mean value obtained for treatment variants $20 \times 4 / 1 \mathrm{~F}$ and $30 \times 4 / 1 \mathrm{~F}$ ) resulted in a volume increase by only $23.6 \%$ comparing to the plants of variant UTC and 
by $20.7 \%$ comparing to those treated in variant SFP. On the other hand, the use of BTHWA together with the standard fungicide program (mean value obtained for treatment variants $20 \times 4$ /SFP and $30 \times 4 /$ SFP) caused a reduction of the plant volume to the level obtained for the plants of variant UTC and SFP.

Analysis of the data from the 2020 experiment showed (Table S5, ESI) positive correlations between the BTHWA cumulative dose and the diameter of the plants and between the BTHWA cumulative dose and the plant area. Moreover, negative correlations were found between the cumulative dose of fungicides and the plant area and between the cumulative dose of fungicides the plant volume. A negative correlation was found between the cumulative dose of fungicide and the plant height, while comparing data from 2019 and 2020, and for the data obtained in 2020.

\subsubsection{The Yield}

As in 2019, no significant differences in the total yield were found between the plants subjected to all variants of treatments (Tables 12 and 13). The treatment according to variant SFP increased a total yield relative to that from the plants of variant UTC, but these values did not differ significantly. The same relations were found for the marketable yield. On the other hand, a significant difference was found for the non-marketable yield. The treatment of plants in variant $20 \times 4 / 0 \mathrm{~F}$ and variant $30 \times 4 / 1 \mathrm{~F}$ resulted in a significantly lower marketable yield compared to that obtained for variant UTC. The use of variant $30 \times 4 / 0 \mathrm{~F}$ and $20 \times 4 / 1 \mathrm{~F}$ resulted in a decrease in the non-marketable yield to $17.15 \mathrm{pcs} / \mathrm{m}^{2}$ and $17.66 \mathrm{pcs} / \mathrm{m}^{2}$, respectively. When referred to that obtained for variant UTC $\left(27.82 \mathrm{pcs} / \mathrm{m}^{2}\right)$ resulted in reduction of non-marketable yield by 39\% and 37\%, respectively. Expressing this parameter in $\mathrm{kg}$ per square meter, the decrease in the non-marketable yield reaches $42 \%$ and $27 \%$. The treatment according to variants $20 \times 4 / 1 \mathrm{~F}$ and variant $30 \times 4 / 1 \mathrm{~F}$ did not provide as good protection from pathogens as the treatment in variants $20 \times 4$ /SFP, $30 \times 4 /$ SFP, and SFP. 
Table 12. Two-way analysis of the effect on selected parameters of yield of all variants of treatment tested in 2020.

\begin{tabular}{|c|c|c|c|c|c|}
\hline & \multirow{2}{*}{ BTHWA } & \multicolumn{3}{|c|}{ Type of Fungicide Treatment } & \multirow{2}{*}{ Mean } \\
\hline & & $\mathbf{0 F}$ & 1F & SFP & \\
\hline \multirow{3}{*}{ Marketable yield (pcs. $/ \mathrm{m}^{2}$ ) } & $20 \times 4$ & $37.01^{\circ}$ & 52.17 & $73.14 *$ & 54.11 \\
\hline & $30 \times 4$ & $39.04^{\circ}$ & 61.29 & $77.38 *$ & 59.23 \\
\hline & Mean & $38.03 \mathrm{~A}^{\circ}$ & $56.73 \mathrm{AB}$ & $75.46 \mathrm{~B}^{*}$ & \\
\hline \multirow{3}{*}{ Non-marketable yield (pcs./m²) } & $20 \times 4$ & $16.00 \mathrm{~b}^{\circ}$ & $14.32 b^{* 0}$ & $6.39 \mathrm{a}^{*}$ & $12.25 *$ \\
\hline & $30 \times 4$ & $13.91 b^{* 0}$ & $15.84 b^{\circ}$ & $4.99 \mathrm{a}^{*}$ & $11.52 *$ \\
\hline & Mean & $14.96 \mathrm{~B}^{* \circ}$ & $14.99 \mathrm{~B}^{* 0}$ & $5.69 \mathrm{~A}^{*}$ & \\
\hline \multirow{3}{*}{ Total yield (pcs. / m²) } & $20 \times 4$ & 53.02 & 66.49 & 79.54 & 66.35 \\
\hline & $30 \times 4$ & 52.95 & 76.94 & 82.37 & 70.75 \\
\hline & Mean & $52.99 \mathrm{~A}$ & $71.71 \mathrm{AB}$ & 80.95 B & \\
\hline \multirow{3}{*}{ Marketable yield $\left(\mathrm{kg} / \mathrm{m}^{2}\right)$} & $20 \times 4$ & 0.3412 & 0.4294 & 0.5783 & 0.4484 \\
\hline & $30 \times 4$ & 0.3425 & 0.5307 & 0.5642 & 0.4790 \\
\hline & Mean & $0.3398 \mathrm{~A}^{\circ}$ & $0.4801 \mathrm{AB}$ & $0.5712 \mathrm{~B}$ & \\
\hline \multirow{3}{*}{ Non-marketable yield $\left(\mathrm{kg} / \mathrm{m}^{2}\right)$} & $20 \times 4$ & $0.1337 b^{\circ}$ & $0.1107 b^{* \circ}$ & $0.0459 a^{*}$ & 0.0968 * \\
\hline & $30 \times 4$ & $0.1055 b^{* 0}$ & $0.1146 b^{* 0}$ & $0.0325 a^{*}$ & $0.0842 *$ \\
\hline & Mean & $0.1197 \mathrm{~B}^{* \circ}$ & $0.1127 \mathrm{~B}^{* \circ}$ & $0.0392 \mathrm{~A}^{*}$ & \\
\hline \multirow{3}{*}{ Total yield $\left(\mathrm{kg} / \mathrm{m}^{2}\right)$} & $20 \times 4$ & 0.4715 & 0.5401 & 0.6243 & 0.5453 \\
\hline & $30 \times 4$ & 0.4476 & 0.6653 & 0.5977 & 0.5632 \\
\hline & Mean & 0.4514 & 0.5927 & 0.6105 & \\
\hline \multirow{3}{*}{ Mean weight of marketable fruit (g) } & $20 \times 4$ & 8.99 & 8.23 & 7.79 & 8.34 \\
\hline & $30 \times 4$ & 8.84 & 8.63 & 7.29 & 8.25 \\
\hline & Mean & $8.92 \mathrm{~B}$ & $8.43 \mathrm{~B}$ & $7.54 \mathrm{~A}$ & \\
\hline
\end{tabular}

Factors in the columns marked as $0 \mathrm{~F}, 1 \mathrm{~F}$, and SFP mean increasing amounts of fungicide treatments, while in rows factors marked as $20 \times 4$ and $30 \times 4$ mean increasing concentration of BTHWA (as described in Table 4). Symbols for the table: Separately for rows and columns, mean values marked with the same capital letters do not differ significantly at $p=0.05$, while mean values that do not differ significantly are not marked with letter; within rows and columns, mean values marked with the same small letters do not differ significantly at $p=0.05$, while mean values that do not differ significantly are not marked with letter; ${ }^{*}$ - denotes significant difference comparing to untreated control (UTC) (Table 13); ${ }^{\circ}$-denotes a significant difference comparing to treatment with standard fungicide program (SFP) (Table 13 ).

Table 13. Separate control groups for Table 12 presenting the effect on selected parameters of yield of variants UTC (untreated control) and SFP (standard fungicide program) in 2020.

\begin{tabular}{ccc}
\hline \multirow{2}{*}{ Parameter } & \multicolumn{2}{c}{ Variant of Treatment } \\
\cline { 2 - 3 } & UTC & SFP \\
\hline Marketable yield $\left(\mathrm{pcs} . / \mathrm{m}^{2}\right)$ & 42.707 & 68.051 \\
Non-marketable yield $\left(\mathrm{pcs} . / \mathrm{m}^{2}\right)$ & $22.562 \beta$ & $4.991 \alpha$ \\
Total yield $\left(\mathrm{pcs} . / \mathrm{m}^{2}\right)$ & 65.277 & 73.042 \\
Marketable yield $\left(\mathrm{kg} / \mathrm{m}^{2}\right)$ & 0.384 & 0.55 \\
Non-marketable yield $\left(\mathrm{kg} / \mathrm{m}^{2}\right)$ & $0.182 \beta$ & $0.0 .034 \alpha$ \\
Total yield $\left(\mathrm{kg} / \mathrm{m}^{2}\right)$ & 0.566 & 0.58 \\
Mean weight of marketable fruit $(\mathrm{g})$ & 7.98 & 7.82 \\
\hline
\end{tabular}

Symbols for the table: separately for rows, mean values marked with different Greek letters differs significantly at $p=0.05$, while mean values that do not differ significantly are not marked with letter. Shadowed columns indicate reference variants of treatment.

No significant differences were found for the average weight of marketable fruit. On the other hand, a negative correlation was found (Table S5, ESI), between the increasing fungicide dose and the decreasing average weight of marketable fruit in the combined analysis of data from 2019 and 2020 and for the analysis of data from 2020. Moreover, no correlation was found between the dose of BTHWA and the average weight of marketable fruit. 


\subsubsection{Plant Infections in the Field and during Storage}

In 2020, the weather conditions were much more favorable for the development of pathogens (Tables 14 and 15). The pathogen showing the greatest pressure was Phytophtora sp., and its share in all the pathogens observed during the experiment was the greatest and the same relations were observed for the parameter describing the presence of all pathogens observed in the field, therefore, we decided to consider a general parameter describing the percentage of fruits infected in the field (\%). Analysis of the mean values of this parameter has shown that the use of BTHWA alone (the values obtained after treatments in variants $20 \times 4 / 0 \mathrm{~F}$ and $30 \times 4 / 0 \mathrm{~F}$ ) resulted in lower percentage of infected fruits when referred to the results of variant UTC, but the difference was not statistically confirmed. The combined use of one fungicide treatment and BTHWA (mean values obtained for treatment variants $20 \times 4 / 1 \mathrm{~F}$ and $30 \times 4 / 1 \mathrm{~F}$ ) also resulted in lower percentage of infected fruits when compared to that achieved in variant UTC, but the difference was statistically confirmed. The use of BTHWA together with the standard fungicide program (mean value obtained for treatment variants $20 \times 4 / \mathrm{SFP}$ and $30 \times 4 / \mathrm{SFP}$ ) resulted in the lowest percentage of infected plant of all variants of treatment and this percentage was statistically the same as that obtained by the treatment in variant SFP. Evaluation of storage capability of strawberry fruits showed no significant differences between all variants of treatment.

\subsubsection{Physicochemical Parameters}

In the experiment of 2020, the firmness of fruits showed a significant decrease as a result of treatment using variant SFP and a significant increase as a result of treatment with BTHWA (variants $20 \times 4 / 0 \mathrm{~F}$ and $30 \times 4 / 0 \mathrm{~F}$ ), see Tables 16 and 17 . The highest firmness was obtained for the fruits from the plants treated only with BTHWA. Their firmness it did not change with increasing BTHWA dose and was not different from that of the fruits from variant UTC. 
Table 14. Two-way analysis of the effects on parameters related to pathogens development of all variants of treatment tested in 2020 .

\begin{tabular}{|c|c|c|c|c|c|}
\hline & \multirow{2}{*}{ BTHWA } & \multicolumn{3}{|c|}{ Type of Fungicide Treatment } & \multirow{2}{*}{ Mean } \\
\hline & & $0 \mathrm{~F}$ & 1F & SFP & \\
\hline \multicolumn{6}{|l|}{ FIELD } \\
\hline \multirow{3}{*}{ Botrytis cinerea $\left(\mathrm{pcs} . / \mathrm{m}^{2}\right)$} & $20 \times 4$ & 2.0275 & $2.4175^{\circ}$ & 0.7801 & 1.7412 \\
\hline & $30 \times 4$ & 1.8977 & $2.4694^{\circ}$ & 0.7274 & 1.6982 \\
\hline & Mean & $1.9626^{\circ}$ & $2.4435^{\circ}$ & 0.7542 & \\
\hline \multirow{3}{*}{ Phytophtora sp. (pcs. $\left./ \mathrm{m}^{2}\right)$} & $20 \times 4$ & $13.9086^{\circ}$ & $11.9054 *$ & $5.5634 *$ & 10.4619 * \\
\hline & $30 \times 4$ & $11.9865 *$ & $12.9678^{\circ}$ & $4.2658 *$ & $9.7401 *$ \\
\hline & Mean & $12.9435 \mathrm{~B}^{* \circ}$ & $12.4407 \mathrm{~B}^{* \circ}$ & $4.9146 \mathrm{~A}^{*}$ & \\
\hline \multirow{3}{*}{ Colletotrichum sp. (pcs. $\left./ \mathrm{m}^{2}\right)$} & $20 \times 4$ & $0.0260 *$ & $0.0000 *$ & $0.0519 *$ & $0.0260 *$ \\
\hline & $30 \times 4$ & $0.0260 *$ & $0.1039 *$ & $0.0000 *$ & $0.0433 *$ \\
\hline & Mean & $0.0260 *$ & 0.0519 * & 0.0260 * & \\
\hline \multirow{3}{*}{ Rhizopus stolonifer (pcs. $/ \mathrm{m}^{2}$ ) } & $20 \times 4$ & 0.0519 & 0.0000 & 0.0000 & 0.0173 \\
\hline & $30 \times 4$ & 0.0000 & 0.1039 & 0.0000 & 0.0346 \\
\hline & Mean & 0.0260 & 0.0641 & 0.0000 & \\
\hline \multirow{3}{*}{ Botrytis cinerea $(\%)$} & $20 \times 4$ & $3.3946^{\circ}$ & $3.2051^{\circ}$ & 1.0142 & 2.538 \\
\hline & $30 \times 4$ & $3.7351^{\circ}$ & $3.1554^{\circ}$ & 0.8389 & $2.5764^{\circ}$ \\
\hline & Mean & $3.5649 \mathrm{~B}^{\circ}$ & $3.1802 \mathrm{~B}^{\circ}$ & $0.9266 \mathrm{~A}^{*}$ & \\
\hline \multirow{3}{*}{ Phytophtora sp. (\%) } & $20 \times 4$ & $27.77 \mathrm{~b}^{\circ}$ & $19.95 \mathrm{ab}^{\circ}$ & $7.7471 \mathrm{a}^{*}$ & 18.49 \\
\hline & $30 \times 4$ & $22.46 \mathrm{ab}^{\circ}$ & $18.24 \mathrm{ab}$ & $4.8862 \mathrm{a}^{*}$ & $15.2 *$ \\
\hline & Mean & $25.12 \mathrm{~B}^{\circ}$ & $19.1 \mathrm{~B}^{* \circ}$ & $6.3166 \mathrm{~A}^{*}$ & \\
\hline \multirow{3}{*}{ Colletotrichum sp. (\%) } & $20 \times 4$ & 0.06 * & $0 *$ & $0.0485 *$ & $0.0362 *$ \\
\hline & $30 \times 4$ & $0.059 *$ & $0.1283 *$ & 0 * & $0.0624 *$ \\
\hline & Mean & $0.0595 *$ & 0.0641 * & 0.0243 * & \\
\hline \multirow{3}{*}{ Rhizopus stolonifer (\%) } & $20 \times 4$ & 0.1029 & 0 & 0 & 0.0343 \\
\hline & $30 \times 4$ & 0 & 0.1645 & 0 & 0.0548 \\
\hline & Mean & 0.0514 & 0.0822 & 0 & \\
\hline \multirow{3}{*}{ Fruits infected (\%) } & $20 \times 4$ & $31.33 b^{\circ}$ & $23.16 b^{\circ}$ & $8.8098 a^{*}$ & $21.1^{\circ}$ \\
\hline & $30 \times 4$ & $26.25 b^{\circ}$ & $21.69 \mathrm{~b}^{* 0}$ & $5.7251 \mathrm{a}^{*}$ & $17.89 *$ \\
\hline & Mean & $28.79 \mathrm{~B}^{\circ}$ & $22.42 \mathrm{~B}^{* \circ}$ & $7.2674 \mathrm{~A}^{*}$ & \\
\hline \multicolumn{6}{|l|}{ STORAGE } \\
\hline \multirow{3}{*}{ Botrytis cinerea $(\%)$} & $20 \times 4$ & 1.5833 & 2.5834 & 0.1667 & 1.4444 \\
\hline & $30 \times 4$ & 3 & 2.5 & 1.5834 & 2.3611 \\
\hline & Mean & 2.2917 & 2.5417 & 0.875 & \\
\hline \multirow{3}{*}{ Phytophtora sp. (\%) } & $20 \times 4$ & 4.3333 & 6.9167 & 6.1667 & 5.8056 \\
\hline & $30 \times 4$ & 8.0833 & 5.3334 & 6 & 6.4722 \\
\hline & Mean & 6.2083 & 6.125 & 6.0833 & \\
\hline \multirow{3}{*}{ Colletotrichum sp. (\%) } & $20 \times 4$ & 0 & 0 & 0 & 0 \\
\hline & $30 \times 4$ & 0.1667 & 0.1667 & 0 & 0.1111 \\
\hline & Mean & 0.0833 & 0.0833 & 0 & \\
\hline \multirow{3}{*}{ Rhizopus stolonifer (\%) } & $20 \times 4$ & 0 & 0.25 & 0.0833 & 0.1111 \\
\hline & $30 \times 4$ & 1.1667 & 0.5 & 0 & 0.5556 \\
\hline & Mean & 0.5833 & 0.375 & 0.0417 & \\
\hline \multirow{3}{*}{ Fruits infected (\%) } & $20 \times 4$ & 5.9167 & 9.75 & 6.4167 & 7.3611 \\
\hline & $30 \times 4$ & 12.42 & 8.5 & 7.5833 & 9.5 \\
\hline & Mean & 9.1667 & 9.125 & 7 & \\
\hline
\end{tabular}

Factors in the columns marked as $0 \mathrm{~F}, 1 \mathrm{~F}$, and SFP mean increasing amounts of fungicide treatments, while in rows factors marked as $20 \times 4$ and $30 \times 4$ mean increasing concentration of BTHWA (as described in Table 4). Symbols for the table: Separately for rows and columns, mean values marked with the same capital letters do not differ significantly at $p=0.05$, while mean values that do not differ significantly are not marked with letter; within rows and columns, mean values marked with the same small letters do not differ significantly at $p=0.05$, while mean values that do not differ significantly are not marked with letter; ${ }^{*}$-denotes significant difference comparing to untreated control (UTC) (Table 15); ${ }^{\circ}$ - denotes a significant difference comparing to treatment with standard fungicide program (SFP) (Table 15$)$. 
Table 15. Separate control groups for Table 14 presenting the effect on selected parameters related Table 2020.

\begin{tabular}{ccc}
\hline Parameter & \multicolumn{2}{c}{ Variant of Treatment } \\
\cline { 2 - 3 } & UTC & SFP \\
\hline FIELD & 2.6923 & 0.3526 \\
Botrytis cinerea $\left(\mathrm{pcs} . / \mathrm{m}^{2}\right)$ & $24.7756 \beta$ & $5.6731 \alpha$ \\
Phytophtora sp. $\left(\mathrm{pcs} / \mathrm{m}^{2}\right)$ & $0.3526 \beta$ & $0.1282 \alpha$ \\
Colletotrichum sp. $\left(\mathrm{pcs} . / \mathrm{m}^{2}\right)$ & 0.0000 & 0.0000 \\
Rhizopus stolonifer $\left(\mathrm{pcs} . / \mathrm{m}^{2}\right)$ & $3.1579 \beta$ & $0.3704 \alpha$ \\
Botrytis cinerea $(\%)$ & $30.6883 \beta$ & $6.1383 \alpha$ \\
Phytophtora $\mathrm{sp} .(\%)$ & $0.4508 \beta$ & $0.1360 \alpha$ \\
Colletotrichum sp. $(\%)$ & 0.0000 & 0.0000 \\
Rhizopus stolonifer $(\%)$ & $34.2970 \beta$ & $6.6446 \alpha$ \\
Fruits infected $(\%)$ & & \\
STORAGE & 1.6667 & 0.6667 \\
Botrytis cinerea $(\%)$ & 8.1667 & 5.8333 \\
Phytophtora sp. $(\%)$ & 0.1666 & 0.0000 \\
Colletotrichum sp. $(\%)$ & 0.0833 & 0.5834 \\
Rhizopus stolonifer $(\%)$ & 10.0833 & 7.0834 \\
Fruits infected $(\%)$ & $\%$ & \\
\hline
\end{tabular}

Symbols for the table: separately for rows, mean values marked with different Greek letters differs significantly at $p=0.05$, while mean values that do not differ significantly are not marked with a letter. Shadowed columns indicate reference variants of treatment.

Table 16. Two-way analysis of the effects on selected physicochemical parameters of fruits of all variants of treatment tested in 2020 .

\begin{tabular}{|c|c|c|c|c|c|}
\hline & \multirow{2}{*}{ BTHWA } & \multicolumn{3}{|c|}{ Type of Fungicide Treatment } & \multirow{2}{*}{ Mean } \\
\hline & & OF & $1 F$ & SFP & \\
\hline \multirow{3}{*}{ Anthocyans (mg/100 g of fruits) } & $20 \times 4$ & $47.3745 \mathrm{~b}^{*}$ & $43.0980 \mathrm{a}^{\circ}$ & $45.0921 \mathrm{~b}$ & $45.1882 \mathrm{~A}$ \\
\hline & $30 \times 4$ & $52.4836 c^{* 0}$ & $46.2983 \mathrm{~b}$ & $45.2830 \mathrm{~b}$ & $48.0216 \mathrm{~B}$ \\
\hline & Mean & $49.9290 \mathrm{~B}^{*}$ & $44.6981 \mathrm{~A}$ & $45.1875 \mathrm{~A}$ & \\
\hline \multirow{3}{*}{ Polyphenols (mg/100 g of fruits) } & $20 \times 4$ & $298.6946 b^{*}$ & $284.3074 \mathrm{a}$ & $298.0145 b^{*}$ & $293.6722 \mathrm{~A}$ \\
\hline & $30 \times 4$ & $306.2806 c^{* 0}$ & $286.0339 \mathrm{a}$ & $296.0526 b^{*}$ & 296.1223 B \\
\hline & Mean & $302.4876 C^{* 0}$ & $285.1706 \mathrm{~A}$ & $297.0335 \mathrm{~B}^{*}$ & \\
\hline \multirow{3}{*}{ Ascorbic acid (mg/100 g of fruits) } & $20 \times 4$ & $44.8829 c^{* 0}$ & $39.1063 a^{* 0}$ & $45.5021 c^{* 0}$ & $43.1638 \mathrm{~A}^{\circ}$ \\
\hline & $30 \times 4$ & $45.4299 c^{* \circ}$ & $42.7957 b^{\circ}$ & $43.6239 \mathrm{~b}^{\circ}$ & $43.9498 \mathrm{~B}^{\circ}$ \\
\hline & Mean & $45.1564 \mathrm{~B}^{\circ}$ & $40.9510 \mathrm{~A}^{\circ}$ & $44.5630 \mathrm{~B}^{\circ}$ & \\
\hline \multirow{3}{*}{ Firmness (N) } & $20 \times 4$ & $1.5005 b^{\circ}$ & $0.9467 a^{*}$ & $0.9477 \mathrm{a}^{*}$ & 1.1317 \\
\hline & $30 \times 4$ & $1.4504 \mathrm{~b}^{\circ}$ & $1.2467 \mathrm{ab}^{\circ}$ & $1.1365 \mathrm{ab}$ & $1.2779^{\circ}$ \\
\hline & Mean & $1.4755 \mathrm{~B}^{\circ}$ & $1.0967 \mathrm{~A}^{*}$ & $1.0421 \mathrm{~A}^{*}$ & \\
\hline \multirow{3}{*}{ Fruit color-L (darkness/lightness) } & $20 \times 4$ & 26.39 & 26.46 & 27.41 & 26.75 \\
\hline & $30 \times 4$ & $27.93^{\circ}$ & 26.7 & 26.14 & 26.92 \\
\hline & Mean & 27.16 & 26.58 & 26.77 & \\
\hline \multirow{3}{*}{ Fruit color-a (green/red) } & $20 \times 4$ & $20.05 \mathrm{ab}$ & $18.75 a^{* 0}$ & $20.35 \mathrm{ab}$ & $19.72 \mathrm{~A}$ \\
\hline & $30 \times 4$ & $22.85 c$ & $21.61 \mathrm{bc}$ & $18.71 \mathrm{a}^{* 0}$ & $21.06 \mathrm{~B}$ \\
\hline & Mean & $21.45 \mathrm{~B}$ & $20.18 \mathrm{AB}$ & $19.53 \mathrm{~A}$ & \\
\hline \multirow{3}{*}{ Fruit color-b (blue/yellow) } & $20 \times 4$ & $12.05 \mathrm{a}$ & $11.51 \mathrm{a}$ & $11.64 \mathrm{a}$ & 11.73 \\
\hline & $30 \times 4$ & $14.36 \mathrm{~b}$ & $12.2 \mathrm{a}$ & $10.46 a^{* \circ}$ & 12.34 \\
\hline & Mean & $13.21 \mathrm{~B}$ & $11.85 \mathrm{AB}$ & $11.05 \mathrm{~A}^{* 0}$ & \\
\hline
\end{tabular}

Factors in the columns marked as $0 \mathrm{~F}, 1 \mathrm{~F}$, and SFP mean increasing amounts of fungicide treatments, while in rows factors marked as $20 \times 4$ and $30 \times 4$ mean increasing concentration of BTHWA (as described in Table 4). Symbols for the table: Separately for rows and columns, mean values marked with the same capital letters do not differ significantly at $p=0.05$, while mean values that do not differ significantly are not marked with letter; within rows and columns, mean values marked with the same small letters do not differ significantly at $p=0.05$, while mean values that do not differ significantly are not marked with letter; ${ }^{*}$-denotes significant difference comparing to untreated control (UTC) (Table 17); ${ }^{\circ}$ - denotes a significant difference comparing to treatment with standard fungicide program (SFP) (Table 17). 
Table 17. Separate control groups for Table 16 presenting the effect on selected physicochemical parameters of fruits of variants UTC (untreated control) and SFP (standard fungicide program) in 2020.

\begin{tabular}{ccc}
\hline \multirow{2}{*}{ Parameter } & \multicolumn{2}{c}{ Variant of Treatment } \\
\cline { 2 - 3 } & UTC & SFP \\
\hline Anthocyans (mg/100 g of fruits) & $44.39 \alpha$ & $46.90 \beta$ \\
Polyphenols (mg/100 g of fruits) & $282.7 \alpha$ & $291.3 \beta$ \\
Ascorbic acid (mg/100 g of fruits) & $42.11 \alpha$ & $48.93 \beta$ \\
Firmness (N) & $1.3672 \beta$ & $0.9209 \alpha$ \\
Fruit color-L & 26.94 & 26.03 \\
(darkness/lightness) & 21.09 & 21.40 \\
Fruit color-a (green/red) & 12.94 & 13.32 \\
Fruit color-b (blue/yellow) & & \\
\hline
\end{tabular}

Symbols for the table: separately for rows, mean values marked with different Greek letters differs significantly at $p=0.05$, while mean values that do not differ significantly are not marked with a letter. Shadowed columns indicate reference variants of treatment.

For the parameters: fruit firmness, anthocyanin content, polyphenols content, and ascorbic acid content, significant differences were found between the fruits from the plants of variant UTC and variant SFP (Tables 16 and 17). The treatment in variant SFP resulted in a significant increase in the content of anthocyanins, polyphenols, and ascorbic acid in the fruits relative to these contents in the untreated plants (variant UTC). Such an increase was also observed as a result of the treatment with BTHWA (variants $20 \times 4 / 0 \mathrm{~F}$ and $30 \times 4 / 0 \mathrm{~F}$ ) aimed at influencing the plant's metabolism. On the basis of the mean value of the content of anthocyanins, polyphenols, and ascorbic acid in the fruits from the plants subjected to variants $20 \times 4 / 0 \mathrm{~F}$ and $30 \times 4 / 0 \mathrm{~F}$, the increase in these parameters relative to their values for the untreated plants (variant UTC) was $12.5 \%, 7 \%$, and $1.7 \%$ respectively.

The treatment of plants only with BTHWA, in variants $20 \times 4 / 0 \mathrm{~F}$ and $30 \times 4 / 0 \mathrm{~F}$, resulted in a significant increase in the content of anthocyanins and polyphenols in fruits compared to those from variants $20 \times 4 / 1 \mathrm{~F}, 30 \times 4 / 1 \mathrm{~F}, 20 \times 4$ /SFP, and $30 \times 4 / \mathrm{SFP}$. A comparison of the effects of treatments in variants $20 \times 4 / 0 \mathrm{~F}$ and $30 \times 4 / 0 \mathrm{~F}$ showed that with increasing BTHWA dose, the content of these substances increased. The treatment in variant $30 \times 4 / 0 \mathrm{~F}$ resulted in the highest content of anthocyanins and polyphenols in fruits from the plants treated according to all variants.

The highest content of ascorbic acid was found in the plants subjected to variant SFP. For the plant subjected to the other variants of treatments, the highest values of these parameters were observed in the fruits from plants treated in variants $20 \times 4 / 0 \mathrm{~F}, 30 \times 4 / 0 \mathrm{~F}$, and $20 \times 4$ /SFP.

\subsubsection{The Storage}

The highest content of dry matter of fruit and the highest value of ${ }^{\circ}$ Brix parameter was found for the fruit from the plants of variant UTC (Tables 18 and 19). The treatment according to variant SFP significantly decreased both these parameters when compared to the values obtained for variant UTC. The fruits from the plants treated in variant $20 \times 4 / 1 \mathrm{~F}$ contained significantly more dry matter than those from the plants treated in variant SFP, but still significantly less than the fruit from the plants of variant UTC. The fruits collected from the plants treated in variant $30 \times 4 / 1 \mathrm{~F}$ were characterized by the lowest dry matter content from among the fruits of the plants subjected to all treatment variants. 
Table 18. Two-way analysis of the effects on selected parameters of fruits of all variants of treatment tested in 2020.

\begin{tabular}{|c|c|c|c|c|c|}
\hline & \multirow{2}{*}{ BTHWA } & \multicolumn{3}{|c|}{ Type of Fungicide Treatment } & \multirow{2}{*}{ Mean } \\
\hline & & $\mathbf{0 F}$ & 1F & SFP & \\
\hline \multirow{3}{*}{$\begin{array}{l}\text { Respiration rate } \\
\qquad\left(\mathrm{mgCO}_{2} / \mathrm{kg}\right)\end{array}$} & $20 \times 4$ & - & $41.7524 \mathrm{a}^{*}$ & $41.1259 \mathrm{a}^{*}$ & $41.4391 \mathrm{~A}^{*}$ \\
\hline & $30 \times 4$ & - & $50.7497 b^{* \circ}$ & $45.7430 \mathrm{ab}^{*}$ & $48.0963 \mathrm{~B}^{* \circ}$ \\
\hline & Mean & - & $46.2510 * 0$ & 43.2844 * & \\
\hline \multirow{3}{*}{$\begin{array}{l}\text { Dry weight of } \\
\text { fruits }(\%)\end{array}$} & $20 \times 4$ & - & $7.6075 b^{* \circ}$ & $7.2892 b^{*}$ & $7.4484 \mathrm{~B}^{* \circ}$ \\
\hline & $30 \times 4$ & - & $6.584 a^{* \circ}$ & $7.1664 b^{*}$ & $6.8752 \mathrm{~A}^{*}$ \\
\hline & Mean & - & $7.0958^{*}$ & $7.2278^{*}$ & \\
\hline \multirow{3}{*}{ Brix (o) } & $20 \times 4$ & - & $7.2078 \mathrm{~b}^{* \circ}$ & $7.4089 c^{* \circ}$ & $7.3083 \mathrm{~B}^{*}$ \\
\hline & $30 \times 4$ & - & $7.2356 \mathrm{~b}^{* \circ}$ & $6.8877 a^{*}$ & $7.0616 \mathrm{~A}^{*}$ \\
\hline & Mean & - & $7.2217 *$ & $7.1483 *$ & \\
\hline
\end{tabular}

Factors in the columns marked as 0F, 1F, and SFP mean increasing amounts of fungicide treatments, while in rows factors marked as $20 \times 4$ and $30 \times 4$ mean increasing concentration of BTHWA (as described in Table 4). Symbols for the table: Separately for rows and columns, mean values marked with the same capital letters do not differ significantly at $p=0.05$, while mean values that do not differ significantly are not marked with letter; within rows and columns, mean values marked with the same small letters do not differ significantly at $p=0.05$, while mean values that do not differ significantly are not marked with letter; ${ }^{*}$ - denotes significant difference comparing to untreated control (UTC) (Table 19); ${ }^{\circ}$ - denotes a significant difference comparing to treatment with the standard fungicide program (SFP) (Table 19).

Table 19. Separate control groups for Table 18 presenting the effect on selected parameters of fruits of variants UTC (untreated control) and SFP (standard fungicide program) in 2020.

\begin{tabular}{|c|c|c|}
\hline \multirow{2}{*}{ Parameter } & \multicolumn{2}{|c|}{ Variant of Treatment } \\
\hline & UTC & SFP \\
\hline Respiration rate $\left(\mathrm{mgCO}^{2} / \mathrm{kg}\right)$ & $61.3769 \beta$ & $36.7526 \alpha$ \\
\hline Dry weight of fruits (\%) & $8.4603 \beta$ & $6.8968 \alpha$ \\
\hline Brix (o) & $8.1311 \beta$ & $6.9078 \alpha$ \\
\hline
\end{tabular}

Symbols for the table: separately for rows, mean values marked with different Greek letters differs significantly at $p=0.05$, while mean values that do not differ significantly are not marked with letter. Shadowed columns indicate reference variants of treatment.

The values of the ${ }^{\circ}$ Brix parameter determined for the fruits from the plants treated according to all variants were significantly lower than those obtained for the fruits from the plants of UTC variant. Of the four tested variants of treatments, the highest value of ${ }^{\circ}$ Brix parameter was found in the fruits from the plant subjected to variant $20 \times 4 /$ SFP. For the plants subjected to the remaining variants of treatment, the ${ }^{\circ}$ Brix parameter was significantly higher than that obtained for variant SFP; however still significantly lower than that obtained for variant UTC.

Another approach assessing the storage capability of strawberry fruit is based on measurements of the respiration rate. The value of this parameter depends on the dry weight of the fruit, the ${ }^{\circ}$ Brix parameter and the degree of plant infection. Higher values of the above-mentioned parameters result in increased amount of released $\mathrm{CO}_{2}$ expressed in $\mathrm{mg} / \mathrm{kg}$ of fruit. The highest respiration rate was recorded for the fruits from the plants of variant UTC. It should be noted that the fruits from the plants subjected to all variants of treatment showed lower respiration rates comparing to those from the plants of variant UTC. Moreover, the respiration rate of the fruits from the plants treated in variants $20 \times 4 / 1 \mathrm{~F}, 20 \times 4 / \mathrm{SFP}$, and $30 \times 4 / \mathrm{SFP}$ did not statistically differ from that obtained for the fruits from the plants treated in variant SFP.

\subsection{Correlations}

The correlation analysis covered the data from 2019 to 2020 (Table S5, ESI). In 2020, it was found that the higher the cumulative dose of BTHWA, the greater the diameter 
and surface area of the canopy of the plant, and the polyphenol content in the fruit, and at the same time, the lower the dry matter content and the level of fruit infection with Colletotrichum sp.

On the other hand, with increasing cumulative dose of the fungicide in 2020, the height of plants, the area and volume of the canopy of plants, the average weight of marketable fruits, the content of dry matter, and ${ }^{\circ}$ Brix in the fruits and the percentage of fruits infested in the field by Phytophtora sp. and in the field and during storage by Bortytis cinerea, decreased.

In 2020, higher levels of anthocyanins and ascorbic acid were positively correlated with the increasing level of polyphenols. The transpiration rate of strawberry fruits during storage was also positively correlated with ${ }^{\circ}$ Brix parameter, firmness of the fruit, and the infestation of fruits by Colletotrichum sp. during storage.

The analysis of correlations of results from both experiments, in 2019 and 2020, must be considered with caution due to drought stress that was present during the 2019 experiment. Nevertheless, it was found that with increasing total dose of BTHWA, the content of polyphenols in the fruits increased, while the number of fruits infected with anthracnose decreased. At the same time, increasing the number of fungicide treatments reduced the plant height and the average weight of healthy fruits. The share of fruits infested in the field by Bortytis cinerea and Phytophtora sp. also decreased. The infestation of the fruits by Botrytis cinerea during storage was also lower. The content of polyphenol in the fruits in both experiments, 2019 and 2020, was negatively correlated with the following parameters: in fruits infected (\%) in the field; percentage of fruits infected with: Phytophtora sp., Colletotrichum sp., and Botrytis cinerea in the field and infected with Phytophtora sp. and Botrytis cinerea during the storage. Nevertheless, it should be remembered that the high polyphenol content in the plants observed in 2019 was partly due to the drought stress. In addition, it should be emphasized that the correlation analysis from both experiments, 2019 and 2020 and only from 2020 showed that with increasing content of polyphenols in the fruits, the content of anthocyanins and ascorbic acid in the fruits increased.

\section{Discussion}

The active substance used in the study, $N$-methoxy- $N$-methylbenzo(1.2.3)thiadiazole7-carboxamide (BTHWA) is a new derivative of benzothiazoles whose effectiveness in inducing plant resistance is known [37]. It has been established that even a small modification of its structure has a significant impact on its physicochemical and biological properties of resulting compound. In contrast to the commercially available preparation containing benzo(1.2.3)thiadiazole-7-carbothioic acid, $S$-methyl ester, in the new substance we studied the $S$-methylester group has been replaced by the amide group: $N$-methoxy- $N$ methylamide, which resulted in obtaining a new inducer of plant resistance, not known in the literature. Its main advantage was a water solubility $(20 \mathrm{mg} / \mathrm{L})$ higher than that of BTH $(7 \mathrm{mg} / \mathrm{L})$. Due to the change in this parameter, BTHWA is better absorbed by plants, does not persist on the plant leaves or in the soil, thus does not cause phytotoxic effects observed when using BTH [20]. As products containing BTH are commercially available (Actigard, BION), a comparative study of the two active substances (BTH and BTHWA) has been performed previously showing that BTHWA activates more effectively than BTH the genes coding PR (pathogenesis related) proteins and other proteins related to the induction of resistance (PAL and NPR1) [20]. Higher activity of BTHWA has been confirmed by the tests with tobacco mosaic virus (TMV) using the plant-pathogen model [20].

BTHWA is a new inducer of systemic acquired resistance (SAR) in plants. Such substances are defined as those stimulating the immunological system's response similar to the pathogen-host response. Moreover, induction of plants resistance in field conditions is likely to be influenced by a number different of factors, including the environment, genotype, crop nutrition, and the extent to which plants have been already induced. Although studies in this area have intensified over the last few years, our understanding of the impact of these factors on the expression of induced resistance is still unsatisfactory [41]. 
According to Amil-Ruiz et al., it seems clear that the ability of a strawberry plant to respond efficiently to pathogens depends first on the physiological status of injured tissue and general ability to recognize and identify the invaders by surface plant receptors, followed by a broad range of induced mechanisms, which include cell wall reinforcement, production of reactive oxygen species, phytoalexin generation, and pathogenesis-related protein accumulation, which are produced in plants as a response to pathogen invasion or interaction through SAR inducers such as BTH or its derivatives like BTHWA [42].

The first experiment was carried out in 2019 in a field with a high density of strawberry plants. It was expected that such conditions would be favorable for pathogens and their abundance would permit better manifestation of differences between the untreated and treated plants. Unfortunately, the vegetative season in 2019 was marred with considerable drought, which not only inhibited the development of pathogens but also, to some degree, stimulated plant resistance mechanisms. The latter phenomenon has been demonstrated by Ayres and Woolacott for barley, which subjected to drought stress was found to increase the plant resistance to powdery mildew [43]. In 2019, the drought was experienced by plants from 14 days before flowering up to 19 days after flowering. The drought stress had a considerable impact on the plant growth, yield of fruit, content of active substances in the plant, physical properties of fruit, and the presence of pathogens. Due to all the above factors no significant differences were noted between UTC and the plants treated with BTHWA or fungicides. Similar relations have been reported by Dietrich et al., who claims that drought stress, fertilization and competition may have a strongly pronounced effect on plants and disturb the effect of BTH because of changed allocation of the plant resources [44]. The impact of the weather conditions on our experiment in 2019 was visible even after the period of rainfall following the drought. As follows from analysis of the content of anthocyanins, polyphenols, and ascorbic acid in the fruit of the control plants, the activation level of defense mechanisms in the plants related to earlier drought stress was so high and pathogens pressure so low that no breaking of defense mechanisms took place, hence no manifestation of disease symptoms on the plants. Therefore, it was expected that no reliable results would be obtained in the experiment aimed at comparing the results of application of fungicides and BTHWA. Moreover, it was expected application of BTHWA inducing defense mechanism of plant even in the absence of pathogens, could result in reduction of total yield [9,12]; however, this did not happen.

Fortunately, in 2020 the situation was different. Due to lower drought stress, lower density of planting and diminished effect of plants competition for, e.g., water absorbed through roots, the contents of anthocyanins, polyphenols, and vitamin $C$ were in general lower and the differences in the contents of the above compounds in plants subjected to particular variants of treatment were mainly assigned to the treatment with BTHWA [45]. Owing to the favorable weather conditions it was possible to analyze the impact of BTHWA in the variants applied on the growth of strawberries. Moreover, weather conditions that did not induce prolonged drought stress also did not stimulate plant defense mechanisms, so the only factor affecting induction of plant resistance was the application of BTHWA. It should be emphasized that the environmental conditions in 2020 were conducive to development of diseases, which permitted pronounced manifestation of the effects of BTHWA applied separately and in combinations with fungicides.

For the plants treated with BTHWA a positive correlation was found between the cumulated BTHWA doses and the plant diameter and plant area size. In contrast, an inverse correlation was noted between the number of treatments with fungicides and the plant area size, plant height, and volumes, these parameters were the lower the greater the number of fungicide treatments. It should be emphasized that replacement of a number of fungicide treatments with BTHWA application alleviated the negative effects of fungicides. The effectiveness of replacement of a number of fungicide treatments with BTHWA application permits limitation of negative effects of fungicides, reduction of their use, and thus reduction of chemical poisoning of the environment, and improvement of plant growth conditions, similarly as suggested by Walters et al. and Ji et al. [41,46]. 
Just as for other SAR inducers, such as chitosan and BTH, their application brings diverse effects on the growth and size of different plants species. According to Mazaro et al., the treatment of strawberries with chitosan may delay fruit ripening, increase their firmness and fruit mass loss reduction [47]. Azami-Sardooei et al. have shown that the BTH treatment of tomato, cucumber, or beans with the same doses and the same frequency of application has brought about different effects on the vegetative development, size of plants and yield [48]. For tomatoes, no changes in the plant size or yield relative to controls were noted, except for the treatment with high concentrations of BTH $(1000 \mathrm{mg} / \mathrm{L})$, when a low level of leaf stunting and a slight leaf scorching could be observed. For cucumber and beans, a reduced plant size, decrease in the plant growth rate, and reduced number of flowers and fruit were observed after a treatment with a dose of $100 \mathrm{mg} / \mathrm{L}$ of BTH [48]. We applied lower doses of BTHWA ranging from 20 to $40 \mathrm{mg} / \mathrm{L}$, to avoid the phytotoxic effects. Application of BTHWA in the concentrations of $20 \mathrm{mg} / \mathrm{L}, 30 \mathrm{mg} / \mathrm{L}$, or $40 \mathrm{mg} / \mathrm{L}$ resulted in stimulation of vegetative development but a fewer number of flowers and limited fruit setting. Interestingly, treatment with BTHWA also resulted in a reduction in the number of fruit in the total yield when compared to that from variant UTC and SFP, however, it has no effect on the mass of total yield and marketable yield.

The strawberry plants treated with BTHWA were found to show greater diameter of and the surface area of the canopy. Although the number of marketable fruits was smaller, the mean mass of a fruit was greater than in variant UTC and SFP. When only fungicides were applied, the outcome was the opposite: the parameters describing the plant size were smaller, the number of fruits was higher, but the mean mass of a fruit was lower. It is reasonable as the smaller overground part of the plant had to provide assimilates to a greater number of fruits than in the plants treated with BTHWA, so the mean mass of a fruit was lower. Our results are consistent with literature data indicating that, in general, fungicides may have negative effects on crop physiology, especially on photosynthesis [49]. A decrease of chlorophyll and inhibition of net photosynthesis were reported after treatment with fludioxonil [50,51], which was one of fungicidal active substances used in our study. An alteration in photosynthesis might lead to a reduction in photo assimilate production, resulting in a decrease in both growth and yield of crop plants [49].

Replacement of four out of five treatments with fungicide by the treatment with BTHWA alleviated the adverse effects of the fungicide. The plant parameters measured: plant size, number of fruits, commercial, and total yield took values intermediate between those achieved when BTHWA and fungicide were applied separately, the effect on the mean mass of fruit was insignificant. As BTH did not show any direct effect on the number of plant pathogens in vitro, it was classified as not antimicrobial [52].

According to preliminary unpublished data, BTHWA has no direct effect on the fungi species such as Alternaria alternata and Trichoderma viride and the bacteria, Erwinia amylovora. The mechanism of BTHWA involves the activation of the genes coding PR proteins and other proteins engaged in induction of resistance (PAL and NPR1). One of the effects of induced resistance is increased content of phenolic compounds [53], anthocyanins [54] and antioxidants [55], which has been also established in our studies concerning the impact of the BTHWA treatment. We found a direct correlation between the content of these substances in the strawberry fruits and the presence of Phytophthora sp. and Colletotrichum sp. In 2020, as a result of BTHWA application the contents of polyphenols, anthocyanins, and vitamin C were much higher than in UTC variant. In the plants treated with SFP, the contents of the above-mentioned substances were significantly higher than in the UTC variant, but lower than in the plants treated with BTHWA.

According to Romanazzia et al., induction of resistance can lead to increased levels of phenolic compounds in the plant tissues [53]. Additionally, Cao et al., have observed that BTH could effectively increase PAL activity and enhance anthocyanins level in strawberry fruit [55]. These authors have suggested that BTH treatment increases phenolic and anthocyanin contents, which could also be a consequence of a combined effect of BTH induction 
of PAL. Previous studies have shown a positive correlation between total phenolics or anthocyanins content and antioxidant activity in some berry fruits [56].

The effect of induced resistance towards Botrytis cinerea is inconclusive. Achuo et al. have proved a positive impact of BTH on tomatoes, but no increased resistance to this species has been observed on tobacco [57]. Moreover, Govrin et al. have not observed a positive effect on Arabidopsis [58]. As reported by Mazaro et al., the treatment with chitosan, also known to induce SAR, led to reduction of the production of ethylene, decrease in the content of sugars, increase in the total content of polyphenols in the fruit, and increased resistance to Botrytis cinerea [48]. According to our observations the effect of BTHWA on Botrytis cinerea is inconclusive as, on the one hand, results of ANOVA did not confirm the positive effect of this substance on development of Botrytis cinerea, but, on the other hand, analysis of the results collected over 2 years proved a positive correlation between the cumulative dose of BTHWA and the content of polyphenols whose presence was strongly negatively correlated with Botrytis cinerea. Taking into account the fact that the content of polyphenols in the plants observed in 2019 was significantly elevated because of the drought stress, it is impossible to estimate to which degree this effect depends on SAR and to which on the high level of polyphenols. More so that according to Hou et al., the treatment with exogenous polyphenols alone may reduce the level of infection with Botrytis cinerea [59].

The ANOVA analysis confirmed the positive effect of treatment with BTHWA, reducing the development of Phytophthora sp.; however, this effect was much weaker than that of the treatment with variant SFP and a bit weaker than that of the treatment with BTHWA and one treatment with a fungicide variant. The effect of BTH through the mechanism of SAR on the limitation of the presence of Phytophthora capsici on the leaves of pepper has been confirmed by Baysal et al. [60]. Similarly, as for Botrytis cinerea, a strong negative correlation has been observed between the content of polyphenols and the presence of Phytophthora sp., which suggests that polyphenols may have contributed to restricted infection with Phytophthora sp. in 2019. The presence of Colletotrichum sp. in 2020 was relatively modest, although a strong negative correlation was noted between the total dose of BTHWA and the coverage with Colletotrichum sp. The correlation between the content of polyphenols and the presence of Colletotrichum sp. was significant but weak, which implies that the restriction of Colletotrichum sp. development was to a greater degree related to the mechanism of SAR than to a direct effect of polyphenols. The impact of the SAR mechanism activated by BTH on the presence of Colletotrichum sp. has also been reported by Lin et al. [61]. No correlation has been found suggesting the effect of fungicide application on the above pathogen, but the effect of fungicides on Colletotrichum sp. has been confirmed by ANOVA. The impact of BTHWA on the development of Rhizopus stolonifer was also considered within the experiment performed, but as the level of attack of this pathogen was very low in general, it was difficult to establish significant differences. The information on the positive effect of SAR mechanism on the infection with Rhizopus stolonifer has been reported by Zhao et al. [62].

For consumers a very important feature is the color of fruits. No differences in the fruit color determined by spectrophotometric method for the plants of variant UTC and SFP. No significant differences in color were also noted between the plants treated according to all variants of treatment. Although the level of anthocyanins in the plants treated only with BTHWA was higher, no significant increase in the parameter describing red color was observed, in contrast to the report by Cocco et al., who claims that the pigments belonging to the anthocyanins group, e.g., pelargonidin 3-glucoside and cyanidin 3-rutinoside are among those responsible for the red color [63].

In the case of fruit firmness, the treatment with BTHWA definitely increased this feature, in contrast to the effect of fungicides causing the notable loss of firmness. It is a very important effect of BTHWA, as the fruits should have the longest possible shelf-life and should be easy for storage. A similar effect has been observed for the muskmelon by $\mathrm{Li}$, et al., who noted that the treatment of plants with BTH retarded the decline of 
fruit firmness, indicating that BTH treatment could downregulate the abundance of some proteins associated with cell structure to strengthen the cell wall and to delay the descent of fruit firmness [64].

Other parameters describing the fruit quality are the degree of ${ }^{\circ}$ Brix and percentage of dry mass. The treatment with fungicides led to decrease in the values of these parameters, but replacement of a certain number of treatments with fungicides with the treatment with BTHWA alleviated this negative effect. Still the highest percentage of dry mass and the highest ${ }^{\circ}$ Brix were obtained for the UTC variant.

Fruit respiration, a parameter describing the fruit storage capability, was the highest for UTC variant, significantly lower for the fruit from the plants treated with BTHWA, and the lowest for the fruits treated according to variant SFP. As no differences in the level of infections between the stored fruit coming from plants subjected to different variants of treatments were observed, the differences in the respiration parameter can be mainly assigned to the content of organic substances in the fruits, including sugars (expressed by ${ }^{\circ}$ Brix and percentage of dry mass). A number of observations have been made on the effect of the treatment with BTH on the fruit storage capability. The treatment of harvested fruit with BTH has been found to significantly limit the level of infections $[56,65]$. However, in our studies no reduction in the level of disease symptoms was observed, but it must be emphasized that the last treatment with BTHWA was applied on ten days before harvesting. The result obtained for variant $20 \times 4 / 1 \mathrm{~F}$ is particularly important, as it indicates that by reducing the number of fungicide treatments, the same respiration rate can be obtained as for the standard fungicide program (variant $20 \times 4$ /SFP and $30 \times 4 / \mathrm{SFP}$ ).

To sum up, the literature reports on the negative effects of substances inducing plant resistance on the plant size, quantity, and quality of harvested fruits, have not been confirmed in the case of the treatment with BTHWA. The greatest improvement in the parameters describing fruit quality was noted for the plants treated only with BTHWA. This positive effect was reduced with increasing number of the treatments with fungicides. The use of BTHWA was also found to have a positive influence on the fruit health. The fruits from the plants treated with BTHWA proved to be less infected with the pathogens Colletotrichum sp. and Phytophthora sp. than those from the UTC variant. The lowest number of infected fruits was obtained from the plants subjected to standard fungicide program, applied either separately or in combination with BTHWA. No effect of the treatment with fungicides or BTHWA on the storage capability of the strawberries was observed with the selected treatment scheme. The fruit harvested from practically all variants of the experiment after 5 days of storage developed symptoms of diseases and the differences between the variants were insignificant.

Taking into account the increased size of the plant, increase in the content of polyphenols, anthocyanins, and ascorbic acid and improved fruit firmness, increase in ${ }^{\circ}$ Brix and the percentage of dry mass of fruit, and at the same time no decrease in the total and commercial yield, it is reasonable to conclude that the treatment with BTHWA has a definite stimulating effect on the plants. The stimulation of vegetative growth is not always a desirable effect if accompanied by a decrease in the parameters describing quality and quantity of the crop. The stimulating effect of BTHWA is noted also when the plants are subjected to treatment with fungicides, which means that the advantages of BTHWA application appear also when it is applied in the standard protection procedure.

As follows from the above-presented results, the effects of the new compound BTHWA in many aspects are similar to those of other SAR inducers, but an interesting point is that the application of this compound stimulates the vegetative development of plants simultaneously reducing the intensity of flowering and fruit setting, which may be important for choosing the date of application in relation to the developmental phase of the plants. It is supposed that the plants that would produce too many flowers and set too many fruits could be treated in the period of flowering not only to activate the SAR mechanism but also to limit the number of fruits. This hypothesis needs verification in further studies extended on other plants, e.g., vegetables, fruit trees, and bushes. Moreover, other new compounds 
capable of activating SAR mechanism in plants [48] should be evaluated not only by the level of induced plant resistance but also by the effect on generative and vegetative growth.

\section{Conclusions}

$N$-methoxy- $N$-methylbenzo(1.2.3)thiadiazole-7-carboxamide (BTHWA), a derivative of BTH, has a positive effect on strawberries manifested by stimulation of growth and limitation of infections with pathogens. According to the collected evidence, the new compound BTHWA shows a similar plant resistance inducing effect as BTH, through the same SAR mechanism. BTHWA has been shown to stimulate vegetative development, while limiting the number of flowers and fruit setting. Its application leads to a significant decrease in the number of fruits in total yield relative to that obtained from variant UTC or SFP, but has no significant effect on the mass of total and commercial yield. The treatment with BTHWA reduces the infections with Phytophthora sp. and Colletotrichum sp. in the field, among others through stimulating increase in the content of polyphenols in the plants. Besides the increased content of polyphenols, also the levels of anthocyanins and vitamin $\mathrm{C}$ was increased as a result of BTHWA treatment. As follows from our experiment, the treatment with BTHWA, even used at a lower dosage of just $20 \mathrm{mg} / \mathrm{L}$ of the working solution, may successfully replace the majority of treatments with fungicides with no significant negative effect on the health of strawberry fruits, and with improvement of the fruit firmness, an increase in ${ }^{\circ}$ Brix and the percentage of dry mass relative to the fruits from the plants treated with full program of fungicides. Unfortunately, the application of BTHWA only in the period of growth did not protect the fruits against the infections with pathogens during storage. The encouraging results obtained in our experiment on strawberry plants are an incentive for continuation of studies on the effects of BTHWA and other new SAR inducers on other crops.

Supplementary Materials: The following are available online at https://www.mdpi.com/article/ 10.3390/agronomy11061031/s1, Table S1: Characteristics of atmospheric conditions during the test in 2019, Table S2: Environmental conditions during the treatments in 2019 Table S3: Characteristics of atmospheric conditions during the test in 2020. Table S4: Environmental conditions during the treatments in 2020, Table S5: Correlation analysis between selected parameters.

Author Contributions: Conceptualization, M.S. (Marcin Smiglak), M.S. (Maciej Spychalski), and R.K.; methodology, M.S. (Marcin Smiglak), M.S. (Maciej Spychalski), R.K., and W.K.; statistical analysis, M.S. (Marcin Smiglak) and W.K.; formal analysis, M.S. (Maciej Spychalski), R.K., T.S., K.P., and A.K.; investigation, M.S. (Maciej Spychalski), R.K., W.K., M.M., A.P., and M.M.-F.; data collection, M.S. (Maciej Spychalski), R.K., W.K., M.M., A.P., and M.M.-F.; writing—original draft preparation, M.S. (Marcin Smiglak), M.S. (Maciej Spychalski), R.K., W.K., and T.S.; writing-review and editing, K.P., A.K., M.M., A.P., and J.P.; supervision, M.S. (Marcin Smiglak), M.S. (Maciej Spychalski), R.K., and W.K.; project administration, M.S. (Marcin Smiglak) and R.K.; funding acquisition, M.S. (Marcin Smiglak) All authors have read and agreed to the published version of the manuscript.

Funding: The "New plant resistance inducers and their application as innovative approach to plant protection against pathogens" project is carried out within the TEAMTECH (POIR.04/04.00-005BD9/17-00) programme of the Foundation for Polish Science co-financed by the European Union under the European Regional Development Fund.

Institutional Review Board Statement: Not applicable.

Informed Consent Statement: Not applicable.

Data Availability Statement: Not applicable.

Conflicts of Interest: The authors declare no conflict of interest.

\section{References}

1. European Commission (EC). The European Biodiversity Strategy 2030: Bringing Nature Back into Our Lives; European Commission: Brussels, Belgium, 2020. Available online: https:/ / eur-lex.europa.eu/legal-content/EN/TXT/?qid=1590574123338\&uri=CELEX: 52020DC0380 (accessed on 26 August 2020). 
2. Klessig, D.F.; Choi, H.W.; Dempsey, D.A. Systemic acquired resistance and salicylic acid: Past, present, and future. Mol Plant-Microbe Interact. 2018, 31, 871-888. [CrossRef] [PubMed]

3. Kunz, W.; Schurter, R.; Maetzke, T. The chemistry of benzothiadiazole plant activators. Pestic. Sci. 1997, 50, 275-282. [CrossRef]

4. Gutierrez, H.A.Q.; Meller-Harel, Y.; David, D.R.; Borenshtein, M.; Shulchany, R.; Elad, Y. Effect of climate parameters on induced resistance in strawberry powdery mildew. IOBC/WPRS Bull. 2012, 78, 239-243.

5. Meller-Harel, Y.; Kolton, M.; Elad, Y.; Rav-David, D.; Cytryn, E.; Ezra, D.; Borenstein, M.; Shulchani, R.; Graber, E.R. Induced systemic resistance in strawberry (Fragaria $\times$ ananassa) to powdery mildew using various control agents. IOBC/WPRS Bull. 2011, $71,47-51$.

6. Poppy, G.M.; Wilkinson, M.J. Gene Flow from GM Plants; Blackwell Publishing: Oxford, UK, 2005; p. 239.

7. Luna, E.; Bruce, T.J.A.; Roberts, M.R.; Flors, V.; Ton, J. Next-generation systemic acquired resistance. Plant Physiol. 2012, 158, 844-853. [CrossRef]

8. Smiglak, M.; Kukawka, R.; Lewandowski, P.; Pospieszny, H. Cationic derivatives of the plant resistance inducer benzo(1,2,3)thiadiazole7-carbothioic acid S-methyl ester (BTH) as bifunctional ionic liquids. Tetrahedron Lett. 2014, 55, 3565-3568. [CrossRef]

9. Canet, J.V.; Dobón, A.; Ibáñez, F.; Perales, L.; Tornero, P. Resistance and biomass in Arabidopsis: A new model for Salicylic Acid perception. Plant Biotechnol. J. 2010, 8, 126-141. [CrossRef]

10. Huot, B.; Yao, J.; Montgomery, B.L.; He, S.Y. Growth-defense tradeoffs in plants: A balancing act to optimize fitness. Mol. Plant 2014, 7, 1267-1287. [CrossRef]

11. Van Butselaar, T.; van den Ackerveken, G. Salicylic acid steers the growth-Immunity tradeoff. Trends Plant Sci. 2020, 25, 566-576. [CrossRef]

12. Groszmann, M.; Gonzalez-Bayon, R.; Lyons, R.L.; Greaves, I.K.; Kazan, K.; Peacock, W.J.; Dennis, E.S. Hormone-regulated defense and stress response networks contribute to heterosis in Arabidopsis F1 hybrids. Proc. Natl. Acad. Sci. USA 2015, 112, E6397-E6406. [CrossRef]

13. Hanssoon, A.S.; Abduljabbar, I.A. Review on the role of salicylic acid in plants. In Sustainable Crop Production, 1st ed.; Hasanuzzaman, M., Ed.; IntechOpen: London, UK, 2020; Chapter 4; pp. 1-6. [CrossRef]

14. Najafian, S.; Khoshkhui, M.; Vahid, T. Effect of salicylic acid and salinity in rosemary (Rosmarinus officinalis L.): Investigation on changes in gas exchange, water relations, and membrane stabilization. Adv. Environ. Biol. 2009, 3, 322-328.

15. Feder-Kubis, J.; Czerwoniec, P.; Lewandowski, P.; Pospieszny, H.; Smiglak, M. Ionic liquids with natural origin component: A path to new plant protection products. ACS Sust. Chem. Eng. 2020, 8, 842-852. [CrossRef]

16. Smiglak, M.; Lewandowski, P.; Kukawka, R.; Budziszewska, M.; Krawczyk, K.; Obrepalska-Steeplowska, A.; Pospieszny, H. Dual functional salts of Benzo[1.2.3]thiadiazole-7-carboxylates as a highly efficient weapon against viral plant diseases. ACS Sust. Chem. Eng. 2017, 5, 4197-4204. [CrossRef]

17. Smiglak, M.; Kukawka, R.; Lewandowski, P.; Budziszewska, M.; Obrepalska-Steplowska, A.; Krawczyk, K.; Zwolińska, A.; Pospieszny, H. New dual functional salts based on cationic derivative of plant resistance inducer-Benzo[1.2.3]thiadiazole-7carbothioic acid, S-Methyl ester. ACS Sust. Chem. Eng. 2016, 4, 3344-3351. [CrossRef]

18. Kukawka, R.; Czerwoniec, P.; Lewandowski, P.; Pospieszny, H.; Smiglak, M. New ionic liquids based on systemic acquired resistance inducers combined with the phytotoxicity reducing cholinium cation. N. J. Chem. 2018, 42, 11984-11990. [CrossRef]

19. Czerwoniec, P.; Lewandowski, P.; Smiglak, M. Derivatives of isonicotinic acid as new efficient systemic acquired resistance (SAR) inducers. ChemistrySelect 2020, 5, 10759-10764. [CrossRef]

20. Frackowiak, P.; Pospieszny, H.; Smiglak, M.; Obrepalska-Stęplowska, A. Assessment of the efficacy and mode of action of Benzo(1,2,3)-Thiadiazole-7-Carbothioic Acids-Methyl ester (BTH) and its derivatives in plant protection against viral disease. Int. J. Mol. Sci. 2019, 20, 1598. [CrossRef]

21. Basu, A.; Nguyen, A.; Betts, N.M.; Lyons, T.J. Strawberry as a functional food: An evidence-based review. Crit. Rev. Food Sci. Nutr. 2014, 54, 790-806. [CrossRef]

22. Giampieri, F.; Forbes-Hernandez, T.Y.; Gasparrini, M.; Alvarez-Suarez, J.M.; Afrin, S.; Bompadre, S.; Quiles, J.L.; Mezzetti, B.; Battino, M. Strawberry as a health promoter: An evidence based review. Food Funct. 2015, 6, 1386-1398. [CrossRef]

23. Cervantes, L.; Ariza, M.T.; Miranda, L.; Lozano, D.; Medina, J.J.; Soria, C.; Martínez-Ferri, E. Stability of fruit quality traits of different strawberry varieties under variable environmental conditions. Agronomy 2020, 10, 1242. [CrossRef]

24. Worldwide Production of Strawberry in 2017. Available online: https: $/ /$ www.google.com $/$ url? sa $=$ t\&rct=j\&q=\&esrc=s\&source= web\&cd=\&ved=2ahUKEwi_z82j39rvAhXi-SoKHUPVBGgQFjAAegQIBBAD\&url=https\%3A\%2F\%2Fedepot.wur.nl\%2F50321 2\&usg=AOvVaw1JQyvZ6iuymtK-pwkMhl82 (accessed on 1 March 2021).

25. Statistics Poland, Production of Agricultural and Horticultural Crops in 2019. Available online: https://stat.gov.pl/download/ gfx/portalinformacyjny/en/defaultaktualnosci/3332/2/4/1/produkcja_upraw_rolnych_i_ogrodniczych_w_2019_r.pdf (accessed on 1 March 2021).

26. Paszko, D.; Pawlak, J.; Wróblewska, W. Yield of two strawberry cultivars depending on the cropping method on the example of a commercial plantation in a specialized horticultural farm. Acta Sci. Pol. Hortorum Cultus 2014, 13, 149-159.

27. Fagherazzi, A.F.; Suek Zanin, D.; Soares dos Santos, M.F.; Martins de Lima, J.; Welter, P.D.; Francis Richter, A.; Regianini Nerbass, F.; Anneliese Kretzschmar, A.; Rufato, L.; Baruzzi, G. Initial crown diameter influences on the fruit yield and quality of strawberry pircinque. Agronomy 2021, 11, 184. [CrossRef] 
28. Meyers, K.J.; Watkins, C.B.; Pritts, M.P.; Liu, R.H. Antioxidant and antiproliferative activities of strawberries. J. Agric. Food Chem. 2003, 5, 6887-6892. [CrossRef]

29. Seeram, N.P.; Lee, R.; Scheuller, S.; Heber, D. Identification of phenolic compounds in strawberries by liquid chromatography electrosprayionization mass spectroscopy. Food Chem. 2006, 97, 1-11. [CrossRef]

30. Tulipani, S.; Mezzetti, B.; Capocasa, F.; Bompadre, S.; Beekwilder, J.; de Vos, C.H.R.; Capanoglu, E.; Bovy, A.; Battino, M. Antioxidants, phenoliccompounds, and nutritional quality of different strawberry genotypes. J. Agric. Food Chem. 2008, 56, 696-704. [CrossRef]

31. Ghaouth, A.E.; Arul, J.; Ponnampalam, R.; Boulet, M. Chitosan coating effect on storability and quality of fresh strawberries. J. Food Sci. 1991, 56, 1618-1620. [CrossRef]

32. Koike, S.T. Crown rot of strawberry caused by Macrophomina phaseolina in California. Plant Dis. 2008, 92, 1253. [CrossRef]

33. Petrasch, S.; Knapp, S.J.; Van Kan, J.A.L.; Blanco-Ulate, B. Grey mould of strawberry, a devastating disease caused by the ubiquitous necrotrophic fungal pathogen Botrytis cinerea. Mol. Plant Path. 2019, 20, 877-892. [CrossRef]

34. Parker, C. Strawberry fields forever: Can consumers see pesticides and sustainability as an issue? Sustain. Sci. 2015, 10, 285-303. [CrossRef]

35. Friends of the Earth Australia. Available online: https://www.foe.org.au/sites/default/files/TheDoseMakesThePoisonFeb2012_ 0.pdf (accessed on 1 March 2021).

36. Seufert, V.; Ramankutty, N.; Foley, J. Comparing the yields of organic and conventional agriculture. Nature 2012, 485, 229-232. [CrossRef]

37. Smiglak, M.; Pospieszny, H.; Kukawka, R.; Lewandowski, P.; Stolarska, O.; Maciejewski, H. Application of 7-Carboxybenzo(1,2,3)Thiadiazole Amides as Plant Stimulants. Patent Application No. WO/2017/017626, 2 February 2017.

38. Tsao, R.; Yang, R. Optimization of a new mobile phase to know the complex and real polyphenolic composition: Towards a total phenolic index using high-performance liquid chromatography. J. Chromatogr. A. 2003, 1018, 29-40. [CrossRef] [PubMed]

39. Giusti, M.; Wrolstad, R.E. Characterization and measurement of anthocyanins by UV-visible spectroscopy. In Handbook of Food Analytical Chemistry; Wiley: Hoboken, NJ, USA, 2004; Volume 2, Chapter 18; pp. 19-31. [CrossRef]

40. Schurter, R.; Kunz, W.; Nyfeler, R. Process and a Composition for Immunizing Plants Against Diseases. U.S. Patent 4,931,581, 6 June 1990.

41. Walters, D.R.; Ratsep, J.; Havis, N.D. Controlling crop diseases using induced resistance: Challenges for the future. J. Exp. Bot. 2013, 64, 1263-1280. [CrossRef] [PubMed]

42. Amil-Ruiz, F.; Blanco-Portales, R.; Munŏz-Blanco, J.; Caballero, J.L. The strawberry plant defense mechanism. A molecular review. Plant Cell Physiol. 2011, 52, 1873-1903. [CrossRef] [PubMed]

43. Ayres, P.G.; Woolacott, B. Effects of soil water level on the development of adult plant resistance to powdery mildew in barley. Ann. Appl. Biol. 1980, 94, 255-263. [CrossRef]

44. Dietrich, R.; Ploss, K.; Heil, M. Growth responses and fitness costs after induction of pathogen resistance depend on environmental conditions. Plant Cell. Environ. 2004, 28, 211-222. [CrossRef]

45. Aschehoug, E.T.; Brooker, R.; Atawater, D.Z.; Maron, J.L.; Callaway, R.M. The mechanisms and consequences of interspecific competition among plants. Annu. Rev. Ecol. Evol. S. 2016, 47, 263-281. [CrossRef]

46. Ji, P.; Yin, J.; Kone, D. Application of acibenzolar- S-methyl and standard fungicides for control of Phytophthora blight on squash Crop Prot. 2011, 30, 1601-1605. [CrossRef]

47. Mazaro, S.M.; Deschamps, C.; May De Mio, L.L.; Biasi, L.A.; De Gouvea, A.; Sautter, C.K. Post harvest behavior of strawberry fruits after pre harvest treatment with chitosan and acibenzolar-s-methyl. Rev. Bras. Frutic. 2008, 30, 185-190. [CrossRef]

48. Azami-Sardooei, Z.; Seifi, H.S.; de Vleesschauwer, D.; Höfte, M. Benzothiadiazole (BTH)-induced resistance against Botrytis cinerea is inversely correlated with vegetative and generative growth in bean and cucumber, but not in tomato. Australas. Plant Pathol. 2013, 42, 485-490. [CrossRef]

49. Petit, A.-N.; Fontaine, F.; Vatsa, P.; Clément, C.; Vaillant-Gaveau, N. Fungicide impacts on photosynthesis in crop plants. Photosynth. Res. 2012, 111, 315-326. [CrossRef]

50. Saladin, G.; Magne, C.; Clement, C. Effects of fludioxonil and pyrimethanil, two fungicides used against Botrytis cinerea, on carbohydrate physiology in Vitis vinifera L. Pest. Manag. Sci. 2003, 59, 1083-1092. [CrossRef]

51. Petit, A.-N.; Fontaine, F.; Clement, C.; Vaillant-Gaveau, N. Photosynthesis limitations of grapevine after treatment with the fludioxonil fungicide. J. Agric. Food Chem. 2008, 56, 6761-6767. [CrossRef]

52. Bektas, Y.; Eulgem, T. Synthetic plant defense elicitors. Front. Plant Sci. 2015, 5, 1-9. [CrossRef]

53. Romanazzi, G.; Sanzani, S.M.; Bi, Y.; Tian, S.; Martínez, P.G.; Alkan, N. Induced resistance to control postharvest decay of fruit and vegetables. Postharvest Biol. Technol. 2006, 122, 82-94. [CrossRef]

54. EL-Metwally, M.A.; Tarabih, M.E.; EL-Eryan, E.E. Effect of application of $\beta$-aminobutyric acid on maintaining quality of crimson seedless grape and controlling postharvest diseases under cold storage conditions. Plant Pathol. J. 2014, 13, 139-151. [CrossRef]

55. Cao, S.; Hu, Z.; Zheng, Y.; Yang, Z.; Lu, B. Effect of BTH on antioxidant enzymes, radical-scavenging activity and decay in strawberry fruit. Food Chem. 2011, 125, 145-149. [CrossRef]

56. Hukkanen, A.; Kostamo, K.; Karenlampi, S.; Kokko, H. Impact of agrochemicals on peronospora sparsa and phenolic profiles in three rubus arcticus cultivars. J. Agric. Food Chem. 2008, 56, 1008-1016. [CrossRef] 
57. Achuo, E.A.; Audenaert, K.; Meziane, H.; Höfte, M. The salicylic acid-dependent defence pathway is effective against different pathogens in tomato and tobacco. Plant Path. 2004, 53, 65-72. [CrossRef]

58. Govrin, E.M.; Levine, A. Infection of Arabidopsis with a necrotrophic pathogen, Botrytis cinerea, elicits various defense responses but does not induce systemic acquired resistance (SAR). Plant Mol. Biol. 2012, 48, 267-276. [CrossRef]

59. Hou, R.; Shi, J.; Ma, X.; Wei, H.; Hu, J.; Tsang, Y.F.; Gao, M.-T. Effect of phenolic acids derived from rice straw on Botrytis cinerea and infection on tomato. Waste Biomass Valorization 2020, 11, 6555-6563. [CrossRef]

60. Baysal, O.; Turgut, C.; Mao, G. Acibenzolar-S-methyl induced resistance to Phytophthora capsici in pepper leaves. Biol. Plant. 2005, 49, 599-604. [CrossRef]

61. Lin, T.C.; Ishizaka, M.; Ishii, H. Acibenzolar-S-methyl-induced systemic resistance against anthracnose and powdery mildew diseases on cucumber plants without accumulation of phytoalexins. J. Phytopathol. 2009, 157, 40-50. [CrossRef]

62. Zhao, Y.; Li, Y.; Zhang, B. Induced resistance in peach fruit as treated by Pichia guilliermondii and their possible mechanism. Int. J. Food Prop. 2020, 23, 34-51. [CrossRef]

63. Cocco, C.; Magnani, S.; Maltoni, M.L.; Quacquarelli, I.; Cacchi, M.; Antunes, L.E.C.; D’Antuono, L.F.; Faedi, W.; Baruzzi, G. Effects of site and genotype on strawberry fruits quality traits and bioactive compounds. J. Berry Res. 2015, 5, 145-155. [CrossRef]

64. Li, X.; Bi, Y.; Wang, J.; Dong, B.; Li, H.; Gong, D.; Zhao, Y.; Tang, Y.; Yu, X.; Shang, Q. BTH treatment caused physiological, biochemical and proteomic changes of muskmelon (Cucumis melo L.) fruit during ripening. J. Proteom. 2015, 120, $179-193$. [CrossRef]

65. Terry, L.A.; Joyce, D.C. Suppression of grey mould on strawberry fruit with the chemical plant activator acibenzolar. Pest Manag. Sci. 2000, 56, 989-992. [CrossRef] 